\title{
1 Selection for cell yield does not reduce overflow metabolism 2 in $E$. coli
}

3

4 Iraes Rabbers ${ }^{1}$, Willi Gottstein ${ }^{1}$, Adam Feist ${ }^{2}$, Bas Teusink ${ }^{1}$, Frank J. Bruggeman ${ }^{1}$, Herwig

5 Bachmann ${ }^{1,3}$

6 'Systems Biology Lab, Vrije Universiteit Amsterdam, 1081 HV Amsterdam, The Netherlands,

$7 \quad 2$ Department of Bioengineering, University of California, San Diego, La Jolla, CA, USA

$8 \quad{ }^{3}$ NIZO Food Research, Ede, The Netherlands

11 Keywords: overflow metabolism, r/k selection, yield, emulsion culturing, metabolic strategy, cell size, experimental 12 evolution

13

14

15 Correspondence: h.bachmann@vu.nl

16 


\section{Abstract}

19 Overflow metabolism is ubiquitous in nature, and it is often considered inefficient because it leads

20 to a relatively low biomass yield per consumed carbon. This metabolic strategy has been described

21 as advantageous because it supports high growth rates during nutrient competition.

22 Here we experimentally evolved bacteria without nutrient competition by repeatedly growing and

23 mixing millions of parallel batch cultures of E. coli. Each culture originated from a water-in-oil

24 emulsion droplet seeded with a single cell. Unexpectedly we found that overflow metabolism

25 (acetate production) did not change. Instead the numerical cell yield during the consumption of the

26 accumulated acetate increased as a consequence of a reduction in cell size. Our experiments and a

27 mathematical model show that fast growth and overflow metabolism followed by the consumption

28 of the overflow metabolite, leads to a higher numerical cell yield and therefore a higher fitness

29 compared to full respiration of the substrate. This provides an evolutionary scenario where

30 overflow metabolism can be favourable even in the absence of nutrient competition. 


\section{Introduction}

32 When microbes compete, fast-growing strategies typically become dominant. While numerous

33 microorganisms have the ability to respire during fast growth on high-quality carbon sources like

34 glucose, many bacteria, yeasts and mammalian cells are known to not make full use of this

35 capability, even when sufficient oxygen is available ${ }^{1-4}$. Instead of efficiently catabolizing the

36 available carbon source to $\mathrm{CO}_{2}$, they produce metabolic by-products like acetate, lactate or ethanol

37 at the expense of metabolic efficiency, i.e. biomass yield (gram biomass/mole carbon source). This

38 phenomenon is termed overflow metabolism (Figure 1A) and has been suggested to be

39 evolutionarily favourable at nutrient excess, because it supports the highest growth rates. It allows

40 microorganisms that employ this strategy to outcompete fully respiratory cells ${ }^{5-7}$. When subjected

41 to low substrate concentrations, cells grow at a lower rate and display full respiratory behaviour,

42 e.g. in chemostats, which is associated with an increase in metabolic efficiency $1,2,6,8$.

44 In nature many microbial species are in spatially structured environments where resources can be

45 localized and the microbes undergo cycles of feast and famine. Their metabolic strategies have

46 adapted to those conditions. Characteristic of such conditions are periods of nutrient excess

47 followed by starvation, similar to batch cultures that are continued until complete depletion of the

48 carbon sources. The winning strategy generates the highest number of viable offspring after a

49 single cycle of feast and famine. Thus, microorganisms are faced with an "optimization problem":

50 the maximal number of viable offspring has to be produced in the shortest possible time given the

51 available resources. In this context, metabolic inefficiency of overflow metabolism is generally

52 considered to be the price for being fast.

54 As (growth) rate selection is associated with the occurrence of overflow metabolism, one would

55 assume that yield selection should result in an increased metabolic efficiency, typically via

56 enhanced respiratory metabolism. One way to ensure that growth rate competition between

57 microorganisms is prevented, and selection of yield becomes possible, is by culturing individual

58 cells in droplets of water-in-oil emulsions (Figure 1B). In this regime each cell gets its own

59 "privatized" amount of substrate within a medium droplet, and does not compete for it with other

60 genotypes, ruling out rate selection. The cells in a droplet can be allowed to grow until depletion

61 of all carbon sources. When L. lactis was subjected to this protocol, the mutant cells that fixed had 
62 shifted their metabolism from inefficient homolactic to the more efficient mixed-acid

63 fermentation. These mutants had a higher biomass yield and numerical cell yield at a reduced

64 growth rate $^{6}$. This was the first experimental illustration of (cell) yield selection.

66 We exploited this emulsion protocol to evolve E. coli MG1655. Unexpectedly we found no

67 reduction of overflow metabolism after experimental evolution, but rather a decrease in cell size,

68 specifically during growth on the overflow metabolite acetate. This led to an increased numerical

69 cell yield (number of cells/mole glucose). Our experiments and a mathematical model show that

70 in a feast-famine regime fast growth and overflow metabolism followed by the consumption of the

71 overflow metabolite can lead to a higher fitness compared to full respiration of the substrate.

73 Results

74 Selection for cell yield does not decrease overflow metabolism

75 The serial propagation of individual microbial cells in emulsion droplets resembles millions of 76 parallel batch cultivations, each inoculated by a single cell. In each droplet, cells can grow for a 77 limited number of generations (in our case 5 to 6 , set by the average droplet size and the available 78 carbon source) before they reach stationary phase. After such a growth period, all droplets are 79 merged, the cells are mixed and diluted, and used to inoculate new droplets for the next round of 80 growth. This protocol (figure 1B) selects for increased numerical cell yield per mole glucose. We 81 wondered if this selection protocol would lead to E. coli strains with an increased metabolic 82 efficiency (i.e. yield of gram biomass/mole glucose) and reduced overflow metabolism (more 83 respiratory). To investigate this, we propagated E. coli MG1655 for 53 transfers in emulsions and 84 determined the growth characteristics of 90 isolates (Supplementary Figure S1). One of these 85 isolates, designated IR1, was characterized in more detail as it showed an increased maximal 86 optical density compared to the wild type. 
bioRxiv preprint doi: https://doi.org/10.1101/2021.05.24.445453; this version posted May 24, 2021. The copyright holder for this preprint (which

was not certified by peer review) is the author/funder, who has granted bioRxiv a license to display the preprint in perpetuity. It is made available under aCC-BY 4.0 International license.

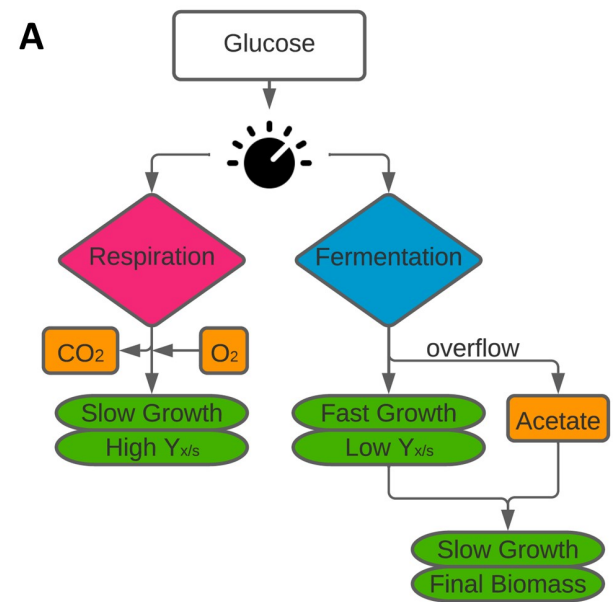

C

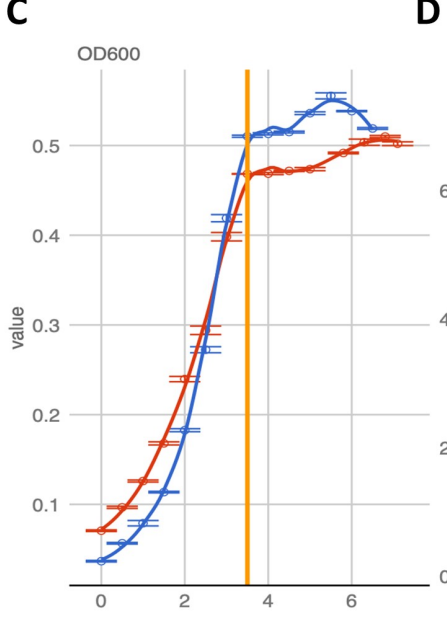

D

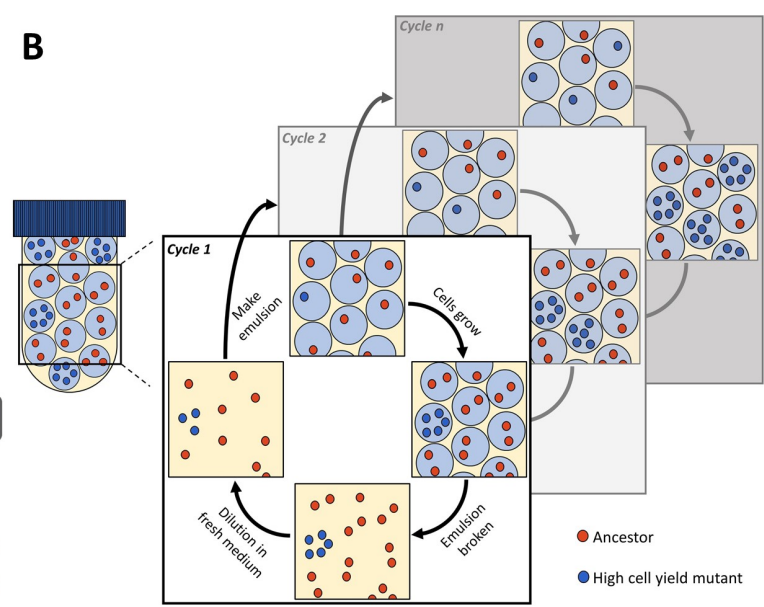

E
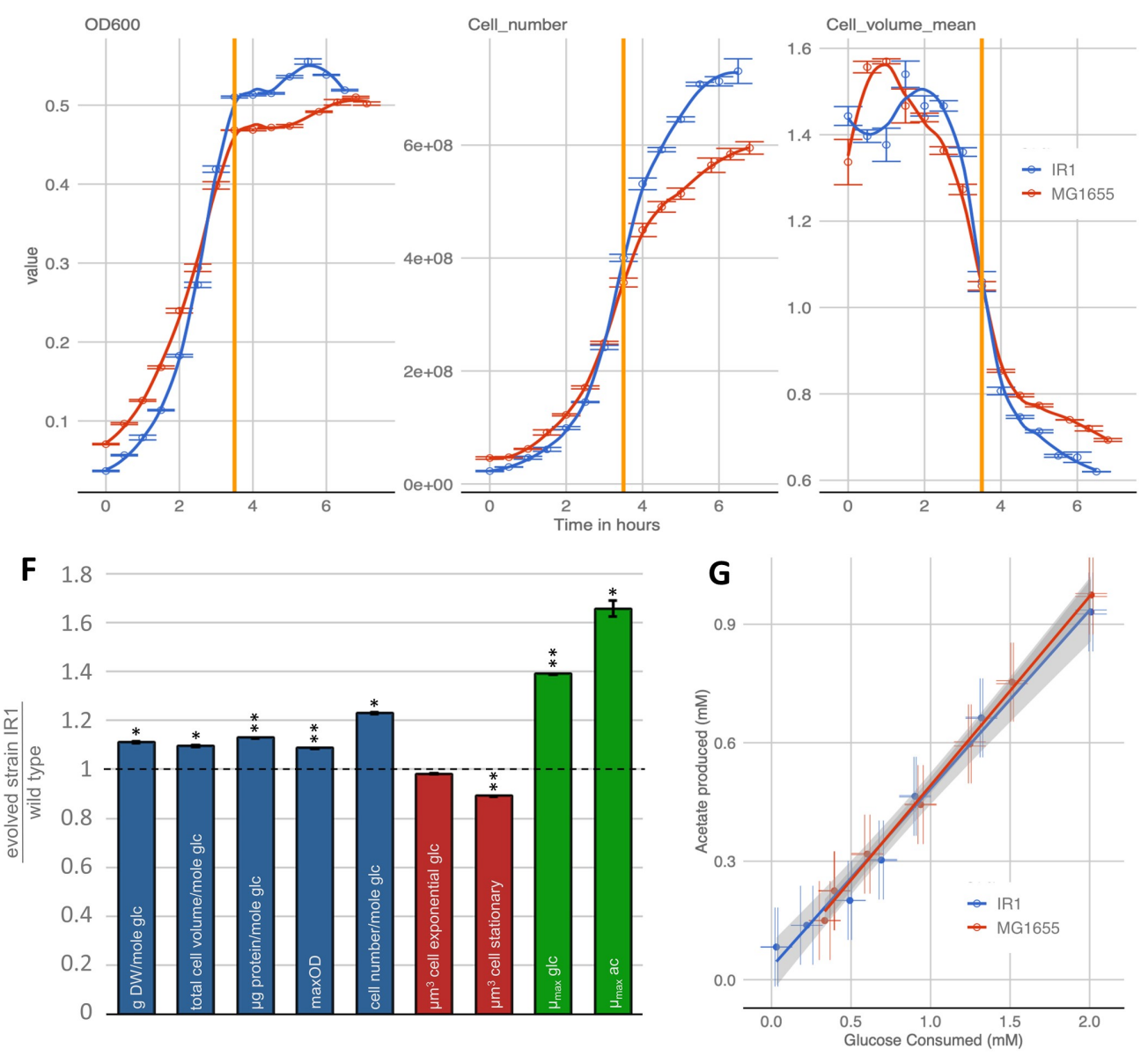

Figure 1. Cell propagation in emulsion droplets resulted in a mutant strain with increased cell yield, but not in a change of acetate production. (A) High biomass yield $\left(Y_{x / s}\right)$ is commonly associated with respiration. Upon depletion of the primary carbon source, growth on overflow metabolites leads to additional biomass formation. (B) Serial propagation of cells grown in emulsion droplets selects for mutants with an increased number of viable offspring per mole glucose (numerical cell yield). (C-E) After 53 transfers in emulsion a selected colony was compared to the wild type. In batch culture fast growth on glucose (depletion is indicated with the vertical orange line) is followed by slow growth on the formed acetate. During growth on acetate the cell 
number (counts/ml) increases much more than the optical density. Upon glucose depletion cell volume $\left(\mu m^{3}\right)$ decreases. The effect of cell number/volume is bigger for the evolved strain IR1 compared to the wild type MG1655. (F) A comparison of evolved strain IR1 normalized to the wildtype revealed significant increases in different biomass and cell yield measures (blue), as well as growth rate (green), while the cell size (red) decreased significantly during the second growth phase on acetate. Error bars represent standard deviations, one star indicates two-sided $t$-test $p$-value $<0.05$, two stars $t$-test $p$-value $<0.005, n=3$. For more details on the underlying data, see Supplementary Table S1 and Supplementary Figure S2. (G) The moles of acetate produced per moles of consumed glucose did not change significantly between the wild type and the selected strain IR1 (ANOVA; F=0.58, F-crit=4.26; $p$ value $=0.45, \alpha=0.05, n=3)$.

Besides the increase in four biomass measures (dry weight, total cell volume, total protein content,

103 optical density) of 9-13\%, strain IR1 also showed an increased growth rate on glucose $(39 \%$ 104 higher) (Fig. 1C-F). Genome sequencing (Supplementary Table S3) revealed an 82bp deletion in 105 the $r p h / p y r E$ region that was previously characterized ${ }^{2,9}$. This mutation alleviates a documented 106 pyrimidine production deficiency of the ancestral strain ${ }^{10-12}$ that limits growth on minimal 107 medium, but not on rich medium. Growth experiments confirmed that IR1 also displays this 108 phenotype (Supplementary Figure S3). We also found that during the glucose-growth phase, IR1 109 shows a 98\% decrease in the production of pyrimidine intermediates orotate and dihydroorotate 110 (Supplementary Figure S2). Together this data indicated that the increase in yield and rate is 111 partially due to mutations that relieve the pyrimidine deficiency of the ancestral strain.

112 Mutants that showed a shift from fermentation towards respiration were not found. The amount of 113 acetate produced per mole of consumed glucose was not altered significantly in the evolved mutant 114 IR1 (Figure 1G). In an additional attempt to isolate mutants with altered overflow metabolism 115 activity, we propagated strain IR1 for another 25 transfers in emulsion droplets. The subsequent 116 characterization of 15 evolved strains showed that all strains still produced acetate (see 117 Supplementary Table S2).

118 Another phenotypic change of the isolated mutant IR, was a decrease in cell volume of $11 \%$ 119 compared to the ancestral strain. This cell size decrease was especially obvious during the second 120 growth phase on acetate, and it corresponds to an increase in cell number of $23 \%$ (Figure 1C) when 121 the glucose is depleted. Re-sequencing revealed a mutation that leads to a stop codon in the ygeR 122 gene (Supplementary Figure S2). This gene is involved in septum formation and cell division, and 123 deletion of it has been shown to reduce cell length ${ }^{13}$. The fact that we isolated mutant strains with 124 reduced cell size and that we were not able to identify strains with decreased overflow metabolism 125 led to an alternative hypothesis: In a feast-famine environment where the evolutionary pressure is 
126 on the overall numerical cell yield, overflow metabolism is actually more efficient than complete

127 respiration when the consumption of the overflow product acetate is taken into the equation.

\section{Biphasic substrate utilization optimizes fitness in feast-famine environments}

130 During growth in batch culture until complete exhaustion of all the carbon sources, microbes are

131 subjected to continuously changing conditions. This resembles a feast and famine cycle with two

132 feast phases (a first phase on glucose and a second phase on acetate), followed by carbon source

133 exhaustion/ famine phase. If the carbon source is a fast fermentable sugar such as glucose then the

134 first phase will be characterized by a high growth rate and a relatively large cell size ${ }^{14}$. As long as

135 the sugar concentration is high, maximizing the growth rate leads to the highest number of

136 offspring produced per unit time. At this stage it is not relevant if the cell is metabolically

137 inefficient, as there is sufficient substrate available. However, when the initial "fast" substrate

138 becomes limiting, cells will switch to growth on the produced overflow metabolite, acetate in the

139 case of E. coli. Growth on an overflow metabolite is always slower than on the initial fast substrate

140 and slow growth is correlated with smaller cell sizes ${ }^{14-18}$.

141 We show that already during the onset of the second growth phase, the cells started to reduce in

142 size to eventually reach a cell volume in stationary phase that is less than half of what it was during

143 exponential growth on glucose (Figure 1E). During this cell size adaptation period, making new

144 offspring cells costs less nutrients than during steady-state growth on acetate, because a mother

145 cell is now larger than a daughter cell and likely does not need to double in size before division.

146 Immediately after glucose depletion, cells therefore need to produce proportionally less biomass

147 to divide into two daughter cells. This leads to a proportionally higher increase in cell number 148 compared to the increase in biomass during the transition from glucose to acetate (Figure 1C-D).

149 This reduction in cell size during the acetate growth phase is substantially larger compared to 150 conditions where no biphasic growth was possible (see Supplementary Information 1). Together, 151 the large differences in cell size on glucose and acetate, the identification of mutants with a smaller 152 cells size and the consequences of this phenotype on the numerical cell yield suggest significant 153 fitness effects of cell size in feast-famine conditions. 
156 The widespread interpretation of the evolutionary benefit of overflow metabolism is biased 157 towards the rate selection argument. However, repeated cycles of growth with finite nutrient 158 supply broadly occurs in nature, and it is likely to have played an important role during the evolution of metabolic strategies. To address whether biphasic substrate utilization is an evolutionary advantageous strategy to maximise the number of offspring in environments with

161 finite resources, we made a mathematical model (see Supplementary Information 2 for derivation 162 and description). The model calculates the number of cells that are made from an initial amount of 163 glucose, given the known biomass yields on glucose and acetate, the fraction $\phi$ of glucose 164 converted into acetate, the cell sizes on glucose and acetate, and the growth rates on glucose and 165 acetate. In agreement with experiments, the growth rate on glucose is a function of $\phi$ : during pure 166 respiratory growth (at $\phi=0$ ) the growth rate is lower than during overflow metabolism 167 (intermediate $\phi)$ and when only acetate would be made from glucose $(\phi=1)$, the growth rate on 168 glucose is zero. A schematic of the model is shown in Figure 2A-B. We used the model to determine the fitness in the case of selection under feast and famine cycles (see Supplementary Information 2).
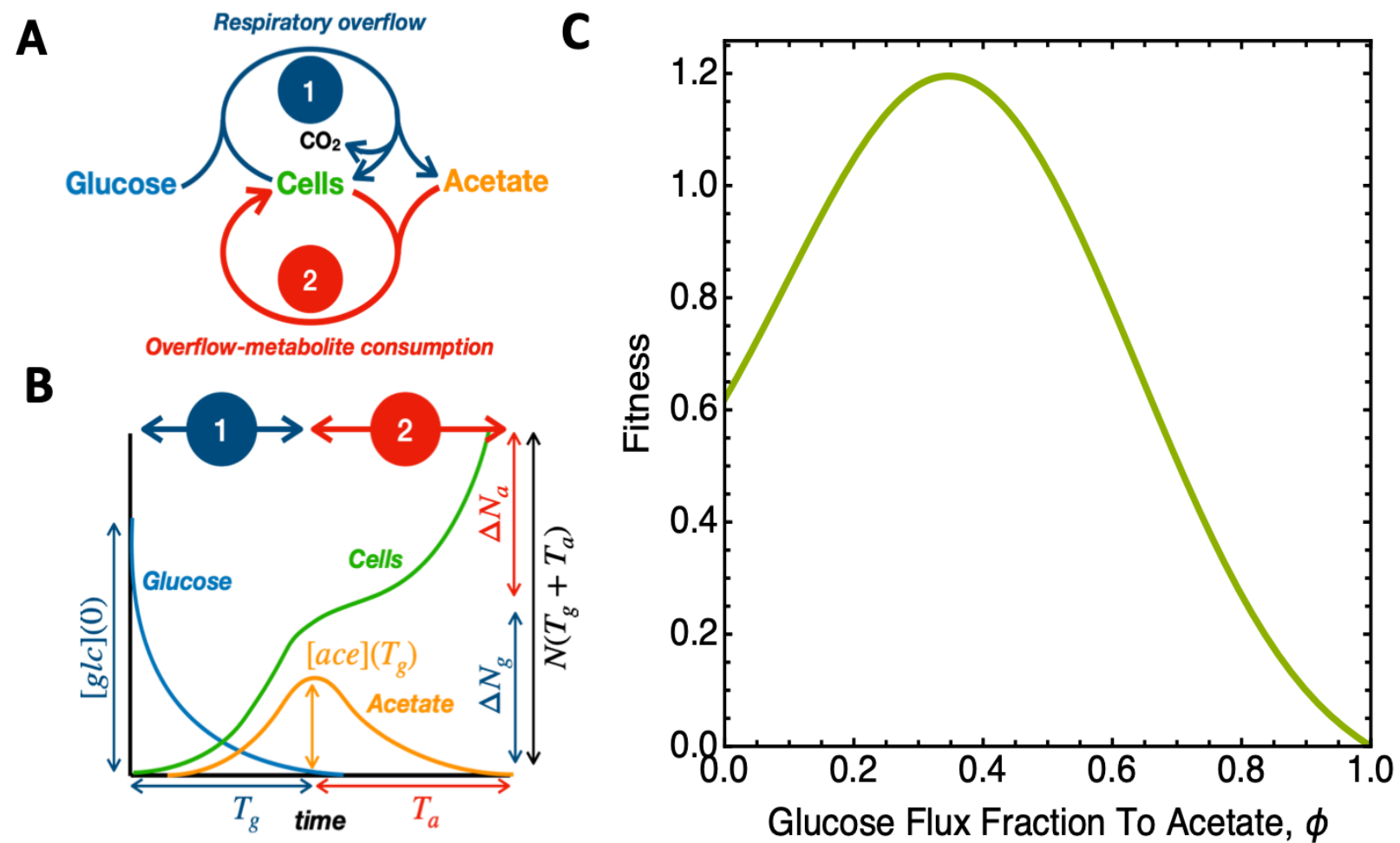

Figure 2. Modelling the fitness consequences of biphasic growth for Escherichia coli. A. Schematic overview of metabolic processes associated with biphasic growth: glucose consumption, acetate formation and growth during the first phase and 


\begin{abstract}
function of time during biphasic growth and introduction of terminology. $C$. We used the model to calculate the fitness $(F$, see Supplementary Information 2) as function of the fraction of the glucose flux directed to acetate formation. Fitness is defined as the logarithm of the factor increase in the number of cells divided by the time until carbon source depletion, i.e. $1 /(T g+T a) ~ I n$ $N(T a+T g) / N(0)$, in agreement with classical evolutionary biology. Parameters values can be found in the table of Supplementary Information 2.
\end{abstract}

Figure $2 \mathrm{C}$ shows that the qualitative model predicts maximal fitness not when cells fully respire $(\phi=0)$ but rather when a fraction of the consumed carbon is first converted to acetate. A fully respiratory cell has a lower fitness than this strategy, indicating that selection during feast-famine conditions selects for a phenotype that combines fast growth (overflow metabolism on glucose) with small cell/high cell number (growth on acetate).

\title{
Discussion
}

Studies describing overflow metabolism as inefficient typically do not include the consumption of overflow metabolites when comparing it to yields of fully respiratory cells. This reasoning is valid during constant conditions of high glucose concentrations where overflow metabolism indeed reduces the maximum attainable ATP (and gram biomass) yield of the utilized carbon source ${ }^{5,19-}$ 21. It does however not apply when the carbon source is depleted, e.g. in batch cultures when utilization of a carbon source is followed by the consumption of the overflow metabolites. Therefore, for a fair comparison, the additional biomass yield on the overflow metabolites needs to be considered as well. In this case it is not immediately clear whether fully respiratory growth is a better evolutionary strategy than overflow metabolism and biphasic growth.

Another important point is that natural selection acts on the number of viable offspring rather than the amount of produced biomass. Interestingly, many bacteria become larger when they grow faster; also $E$. coli is known to have a positive correlation between growth rate and cell size ${ }^{15-18}$. This occurs when the generation time is shorter than the DNA replication time, necessitating mother cells to start DNA replication for their future progeny ${ }^{22-24}$. During evolution on a finite nutrient supply however, it pays off to make a higher number of cells per unit nutrient, and this can be achieved by making smaller cells. A fast growth rate that supports an evolutionary advantage under nutrient excess, therefore has a trade-off with a lower number of offspring per unit of substrate. This trade-off is driven by cell size and independent from metabolic efficiency. An optimization problem thus occurs, where small (but slow) phenotypes would generally be 
outgrown by faster growing cells during nutrient competition. We circumvented this trade-off by serially propagating cells in emulsion droplets where single cells are allowed to grow until nutrient

210 exhaustion in physically separated environments. In this regime mutants that produce more

211 offspring will seed more droplets in the next round and increase in frequency.

212 Against initial expectations, full respiration was not found to be a competitive strategy when rate

213 selection was excluded. While selection in emulsion led to increased metabolic efficiency,

214 biomass- and cell-yield in L $_{\text {lactis }}{ }^{6}$, we found that in E. coli the utilization of overflow metabolism

215 was unaffected. However, we did select for a mutant with a smaller cell size, which is possibly

216 linked to a single base deletion in $y g e R, a$ gene known to affect the cell size ${ }^{13}$. We identified two

217 reasons for the difference in the outcome between the L. lactis study and our experiments i) E. coli

218 is able to consume the overflow metabolite which L. lactis cannot, and ii) when growing on the

219 overflow metabolite, the cell number of $E$. coli increases disproportionately compared to the

220 biomass increase.

221 Our results show that overflow metabolite production and its subsequent utilization maximizes the 222 number of produced offspring irrespective of the available substrate concentration. At high 223 substrate concentrations the growth rate will be maximized while at limiting substrate 224 concentrations a minimization of cell size (maximization of cell number) will occur after the initial 225 "fast" substrate is depleted. This allows the optimization of fitness in dynamic environments. 226 Maximizing the production rate of offspring through sequential substrate utilization seems a very 227 elegant solution that might apply to numerous organisms. For instance the secretion of ethanol, 228 lactate or acetate and their subsequent consumption are broadly encountered ${ }^{25-27}$. Like for E. coli, 229 other organisms showing such behaviour are also described to have a positive correlation between 230 growth rate and cell size $\mathrm{s}^{6,18,28}$. This makes it plausible that a similar fitness maximization strategy 231 in dynamic environments might apply to a broad range of organisms.

232 Attempts to engineer Crabtree negative yeasts and E. coli have been only partially successful and 233 typically the obtained strains are growing poorly or showing unexpected metabolic activities ${ }^{29}$. 234 This points to overflow metabolism being a robust property of the metabolic networks that are 235 difficult to overcome. However, Crabtree negative yeasts are known and it would be interesting to 236 understand under which conditions they might have evolved ${ }^{30,31}$.

237 There are numerous computational approaches that predict the shift from respiration towards 238 overflow metabolism, based on biochemical and biophysical constraints. These studies include for 
example flux balance analysis (FBA), where the optimal metabolic flux distribution is predicted

240 that supports high growth rates; trade-offs due to membrane crowding; and optimization of

241 proteome allocation to minimize the investment associated with the costly respiratory machinery ${ }^{32-}$

$242 \quad 38$. However, besides some studies in yeast where the main argument is that overflow metabolites

243 lead to a fitness advantage due to their toxicity for competing organisms (Make-Accumulate-

244 Consume hypothesis) $27,30,39$ the role of evolutionary perspectives are less investigated. The

245 discussion of overflow metabolism in literature and textbooks typically neglects the fact that the

246 secreted overflow metabolite is often further metabolized. Our results argue for the consideration

247 of the consumption of the overflow metabolite as it likely played a role during evolution in natural

248 environments. This is corroborated by a recent study on the regulation of overflow metabolism ${ }^{40}$.

249 Full respiration and reaching the maximal biomass yield are only seen at low substrate

250 concentrations. This might be a rather artificial situation which is created for instance in

251 chemostats. In nature cells are often exposed to dynamic feast-famine cycles, and spatial structure

252 that leads to variations in the selection pressure.

253 If rate selection would be the only force to favour overflow metabolism one might expect higher

254 acetate fractions to be produced by the wild type strain. The fact that in most cases only a small

255 fraction of the flux is directed towards acetate argues for other (additional) selective forces, such

256 as maximizing cell number. In studies by LaCroix et al. ${ }^{2}$ and Long at al. ${ }^{38}$ rate selection was applied

257 to the same E. coli MG1655 wild type strain. They found a positive correlation between the acetate

258 production and growth rates in the wild type and evolved strains. Such an increase in overflow

259 metabolism at increasing growth rates has been reported in a number of other studies as well ${ }^{3,7,41,42}$.

260 This might indicate that the natural environment from which the wild type strain was isolated was

261 not purely selective for growth rate.

262 Another aspect of natural environments is the possibility of multiple species or strains coexisting.

263 A 'cheater' strain that consumes the acetate before the producer strain can benefit from it would 264 potentially argue against a beneficial effect of overflow metabolism beyond growth rate 265 maximization ${ }^{43}$. However, growth on acetate is typically slow, so even if such a strain would be 266 present at high frequency in the population, its consumption rate would still be significantly lower 267 than what is needed to fully deplete this substrate before the fast growing/acetate producing 268 biomass starts consuming it. In order to pose significant competition, the acetate consumer would 269 therefore need to grow at a similar rate as the acetate producer. Almost all growth rates we found 
270 for diverse organisms on acetate were substantially lower than this (see Supplementary Table S5

271 for a number of examples of glucose and acetate growth rate ratios), except for an Acinetobacter

272 strain that displays an exceptionally high growth rate on acetate of $0.91 \mathrm{~h}^{-1} 44$.

273 In conclusion, this study shows an unexplored consequence of overflow metabolism. It is not only

274 a strategy for fast growth at excess substrate conditions, but it also maximizes the number of

275 offspring in dynamic conditions with regular episodes of finite substrate concentrations. From an

276 evolutionary perspective overflow metabolism is potentially selected for because it maximizes the

277 number of offspring in such dynamic environments, be it through a fast growth rate or the

278 minimization of the cell size. Our results argue for a revisited perspective when investigating

279 metabolic strategies, as currently consumption of overflow metabolites and the role of cell

280 numbers during selection are neglected when fermentation is compared to full respiration. 


\section{Material and Methods}

\section{Strains and media}

283 For experimental evolution Escherichia coli K12 substr. MG1655 (isolate BOP27 obtained from

284 Palsson lab at UCSD) was used. The experiments were initiated from a single colony glycerol

285 stock which was cultured in 3 biological replicates. Strains were cultured at $37^{\circ} \mathrm{C}$ using M9

286 minimal medium ${ }^{2}$ supplemented with $2.5 \mathrm{mM}$ glucose. The same medium was used throughout

287 this study.

\section{Culturing in emulsion}

290 A fully-grown cell culture of $E$. coli was diluted to a concentration of $\sim 2 \cdot 10^{6} \mathrm{cells}^{-1} \mathrm{ml}^{-1}$ in $\mathrm{M} 9$ 291 medium supplemented with $2.5 \mathrm{mM}$ glucose. Using $700 \mu \mathrm{l}$ of the diluted cell suspension and 300

$292 \mu$ l Novec HFE 7500 fluorinated oil (3 M, Maplewood, MN, USA) containing 0.1\% Pico-Surf ${ }^{\mathrm{TM}}$ 293 surfactant (Dolomite Microfluidics) emulsion where prepared as described earlier ${ }^{6}$. In such an 294 emulsion approximately 1 in 10 droplets $(\sim 50 \mu \mathrm{m}$ in diameter) will be inoculated with a single cell 295 (following a Poisson distribution). After overnight incubation at $37^{\circ} \mathrm{C}$, the emulsions were broken 296 using perfluoroctanol (PFO)(Alfa Aesar) and the cultures were diluted in fresh medium to repeat 297 the process ${ }^{6}$.

298 To ensure aerobic growth was supported, the oil was saturated with pressurized atmospheric air 299 prior to use. Sufficient $\mathrm{O}_{2}$ supply was confirmed by measuring growth on a non-fermentable 300 carbon source (data not shown).

\section{Growth curve measurements}

303 Strains of interest were precultured and propagated to a 96-wells plate. The spaces between wells 304 were filled with $0.9 \%$ saline solution, and the plate sealed with parafilm to reduce evaporation 305 from the wells. Growth was measured every 5 minutes, with shaking in between, overnight in a 306 SpectraMax ${ }^{\circledR}$ plate-reader, at $600 \mathrm{~nm}$ and $37^{\circ} \mathrm{C}$. Using the $\mathrm{R}$ software environment, growth rates 307 and maximum ODs were determined per strain as described earlier ${ }^{6}$.

308 Alternatively, growth was measured manually. Strains were grown in $250 \mathrm{ml}$ Erlenmeyer flasks, 309 shaking at $220 \mathrm{RPM}$, at $37^{\circ} \mathrm{C}$. Every 30 minutes samples were taken to measure $\mathrm{OD}_{600}$ in cuvettes. 
312 After the experimental evolution 90 single colonies were randomly picked from the three parallel

313 cell cultures and transferred to a 96-wells plate containing $200 \mu \mathrm{M} 9+2.5 \mathrm{mM}$ glucose per well.

314 Six wells were inoculated with the wild type strain. After overnight growth, $20 \mu \mathrm{l}$ from each well

315 was transferred to a 96-wells plates containing fresh medium for proper growth curve

316 measurements. Glycerol was added to a final concentration of $12 \%$ and the plates were frozen at -

$31780^{\circ} \mathrm{C}$. Growth curves were analysed for growth rates and maximal ODs. Several strains per

318 replicate culture were selected for further analysis, based on the maximal OD compared to the

319 wildtype.

\section{Cell number and volume measurements}

322 Cell number and volume were determined using the Coulter Counter ${ }^{\circledR}$ Multisizer 3 (settings: 323 aperture $30 \mu \mathrm{m}$; $\mathrm{kd} \mathrm{41}$; current $800 \mu \mathrm{A}$; gain 16; sizing threshold $0.3 \mu \mathrm{m}$ ) after adding $50 \mu \mathrm{l}$ cell 324 culture to $10 \mathrm{ml}$ ISOTON II electrolyte.

\section{Metabolic product measurements with HPLC}

327 HPLC analysis was done on the $(0.2 \mu \mathrm{m})$ filtrate of the culture supernatant to determine the 328 metabolic products. The HPLC (Shimadzu LC20, 300x7.8mm) with an ion exclusion column 329 Rezex ROA Organic Acid $\mathrm{H}+(8 \%)$, was run with $5 \mathrm{mM} \mathrm{H}_{2} \mathrm{SO}_{4}$, kept at $55^{\circ} \mathrm{C}$ at a flow rate of 0.5 $330 \mathrm{ml} \cdot \mathrm{min}^{-1}$. Calibrations were done with formate, lactate, acetate, orotate and dihydroorotate.

\section{Glucose determinations}

333 Given the high concentration of phosphate in the M9 medium, and the overlap of this compound

334 with glucose in the HPLC chromatogram, enzymatic glucose determinations were used to 335 complete the metabolic profile. This was done by preparing a reaction mixture containing (final 336 concentrations) PIPES pH=7.0 (14.627 mM), NADP ${ }^{+}(0.286 \mathrm{mM})$, ATP $(0.571 \mathrm{mM}), \mathrm{MgSO} 4$

337 (1.428 mM), hexokinase $(30 \mathrm{U} / \mathrm{ml})$, and glucose-6-phosphate dehydrogenase $(35 \mathrm{U} / \mathrm{ml})$. In a 96338 wells plate, $22 \mu \mathrm{l}$ of sample or standard containing known concentrations of glucose were added 339 to each well, then $178 \mu \mathrm{l}$ of reaction mixture was added to every sample/standard. This was mixed, 340 incubated for $\sim 30$ minutes at $30^{\circ} \mathrm{C}$, and measured at $340 \mathrm{~nm}$ until the curves were stationary. 341 Glucose concentrations were calculated using the calibration curve (measured in duplicate), based 342 on the final $A_{340 .}$ 


\section{Protein content, dry weight}

345 Total protein content of the selected strains was determined following the protocol of the Pierce $\mathbb{R}$

346 BCA Protein Assay Kit. To prepare the samples for this assay, $2 \mathrm{ml}$ of culture was transferred to an Eppendorf tube, washed in $0.9 \%$ saline solution, and the cell pellet was re-dissolved in $200 \mu \mathrm{l}$

348 of saline. $50 \mu \mathrm{l}$ of SDS (10\%) was added, and the samples were incubated at $90^{\circ} \mathrm{C}$ for one hour.

349 Of these samples, and a set of calibration samples with known BSA concentrations, $25 \mu 1$ was 350 transferred to a 96-wells plate and $200 \mu \mathrm{l}$ of reagent (Pierce® BCA Protein Assay Kit; Reagent A:

351 Reagent $B=50: 1$ ) was added. Sample and reagent were mixed by shaking on a plate-shaker for 35230 seconds, then incubated at $37^{\circ} \mathrm{C}$ for 30 minutes. Protein content was subsequently determined 353 in a SpectraMax ${ }^{\circledR}$ plate-reader at $562 \mathrm{~nm}$, and data analysed using the BSA-calibration curves 354 (measured in duplicate), based on the final $\mathrm{A}_{562}$.

355 The dry weights of the selected strains were determined by filtering $50 \mathrm{ml}$ of cell culture through 356 a previously dried $0.2 \mu \mathrm{m}$ pore nitrocellulose filter using a vacuum pump, drying these filters at $35760^{\circ} \mathrm{C}$ to a constant weight and determining the difference in weight before and after the application 358 of the samples to the filters, using a precision scale.

\section{Genome re-sequencing}

361 Genomic DNA was isolated using a Promega Wizard DNA purification kit. The quality of DNA 362 was assessed with UV absorbance ratios by using a NanoDrop apparatus. DNA was quantified by 363 using a Qubit dsDNA high-sensitivity assay. Paired-end resequencing libraries were generated 364 using an Illumina Nextera XT kit with $1 \mathrm{ng}$ of input DNA total. Sequences were obtained using an 365 Illumina Miseq with a PE500v2 kit. The Breseq pipeline ${ }^{45}$ version 0.23 with bowtie2 was used to 366 map sequencing reads and identify mutations relative to the E. coli K-12 substr. MG1655 genome 367 (NCBI accession NC_000913.2). All samples had an average mapped coverage of at least 25.

\section{References}

$370 \quad$ 1. Jasmin, J.-N. J.-N., Dillon, M. M. \& Zeyl, C. The yield of experimental yeast populations declines during selection. Proc.

372 2. LaCroix, R. A. et al. Use of adaptive laboratory evolution to discover key mutations enabling rapid growth of Escherichia 373 coli K-12 MG1655 on glucose minimal medium. Appl. Environ. Microbiol. 81, 17-30 (2015).

374 3. Van Hoek, P., Van Dijken, J. P. \& Pronk, J. T. Effect of specific growth rate on fermentative capacity of baker's yeast. 
Appl. Environ. Microbiol. 64, 4226-33 (1998).

4. Xu, B., Jahic, M., Blomsten, G. \& Enfors, S. O. Glucose overflow metabolism and mixed-acid fermentation in aerobic large-scale fed-batch processes with Escherichia coli. Appl. Microbiol. Biotechnol. 51, 564-571 (1999).

5. Molenaar, D., van Berlo, R., de Ridder, D. \& Teusink, B. Shifts in growth strategies reflect tradeoffs in cellular economics. Mol. Syst. Biol. 5, 323 (2009).

6. Bachmann, H. et al. Availability of public goods shapes the evolution of competing metabolic strategies. Proc. Natl. Acad. Sci. U. S. A. 110, 14302-14307 (2013).

7. Thomas, T. D., Ellwood, D. C. \& Longyear, V. M. C. Change from homo- to heterolactic fermentation by Streptococcus lactis resulting from glucose limitation in anaerobic chemostat cultures. J. Bacteriol. 138, 109-17 (1979).

8. Garrigues, C., Loubiere, P., Lindley, N. D. \& Cocaign-Bousquet, M. Control of the shift from homolactic acid to mixedacid fermentation in Lactococcus lactis: Predominant role of the NADH/NAD+ ratio. J. Bacteriol. 179, 5282-5287 (1997).

9. Conrad, T. M. et al. Whole-genome resequencing of Escherichia coli K-12 MG1655 undergoing short-term laboratory evolution in lactate minimal media reveals flexible selection of adaptive mutations. Genome Biol. 10, (2009).

10. Valgepea, K., Adamberg, K. \& Vilu, R. Decrease of energy spilling in Escherichia coli continuous cultures with rising specific growth rate and carbon wasting. BMC Syst. Biol. 5, 106 (2011).

11. Jensen, K. F. The Escherichia coli K-12 'wild types' W3110 and MG1655 have an rph frameshift mutation that leads to pyrimidine starvation due to low pyrE expression levels. J. Bacteriol. 175, 3401-7 (1993).

12. PARDEE, A. B. \& YATES, R. A. Control of pyrimidine biosynthesis in Escherichia coli by a feed-back mechanism. J. Biol. Chem. 221, 757-70 (1956).

13. Uehara, T., Dinh, T. \& Bernhardt, T. G. LytM-domain factors are required for daughter cell separation and rapid ampicillin-induced lysis in Escherichia coli. J. Bacteriol. 191, 5094-5107 (2009).

14. Si, F. et al. Invariance of Initiation Mass and Predictability of Cell Size in Escherichia coli. Curr. Biol. 27, 1278-1287 (2017).

15. Delong, J. P., Okie, J. G., Moses, M. E., Sibly, R. M. \& Brown, J. H. Shifts in metabolic scaling, production, and efficiency across major evolutionary transitions of life. Proc. Natl. Acad. Sci. 107, 12941-12945 (2010).

16. Schaechter, M., MaalOe, O. \& Kjeldgaard, N. O. Dependency on Medium and Temperature of Cell Size and Chemical Composition during Balanced Growth of Salmonella typhimurium. J. Gen. Microbiol. 19, 592-606 (1958).

17. Volkmer, B. \& Heinemann, M. Condition-Dependent Cell Volume and Concentration of Escherichia coli to Facilitate Data Conversion for Systems Biology Modeling. 6, 1-6 (2011).

19. MacLean, R. C. The tragedy of the commons in microbial populations: Insights from theoretical, comparative and experimental studies. Heredity 100, 233-239 (2008). chemostat cultures of Saccharomyces cerevisiae. Appl. Environ. Microbiol. 55, 468-77 (1989). 
414 23. Bipatnath, M., Dennis, P. P. \& Bremer, H. Initiation and velocity of chromosome replication in Escherichia coli B/r and K-12. J. Bacteriol. 180, 265-73 (1998).

24. Donachie, W. D. Relationship between Cell Size and Time of Initiation of DNA Replication. Nature 219, 1077-1079 (1968).

25. Goffin, P., Lorquet, F., Kleerebezem, M. \& Hols, P. Major role of NAD-dependent lactate dehydrogenases in aerobic lactate utilization in Lactobacillus plantarum during early stationary phase. J. Bacteriol. 186, 6661-6666 (2004).

26. El-Mansi, E. M. T. \& Holms, W. H. Control of carbon flux to acetate excretion during growth of Escherichia coli in batch and continuous cultures. J. Gen. Microbiol. 135, 2875-2883 (1989).

27. Thomson, J. M. et al. Resurrecting ancestral alcohol dehydrogenases from yeast. Nat. Genet. 37, 630-635 (2005).

28. Johnston, G. C., Ehrhardt, C. W., Lorincz, A. \& Carter, B. L. Regulation of cell size in the yeast Saccharomyces cerevisiae. J. Bacteriol. 137, 1-5 (1979).

29. De Mey, M., De Maeseneire, S., Soetaert, W. \& Vandamme, E. Minimizing acetate formation in E. coli fermentations. J. Ind. Microbiol. Biotechnol. 34, 689-700 (2007).

30. Hagman, A., Säll, T., Compagno, C. \& Piskur, J. Yeast “Make-Accumulate-Consume" Life Strategy Evolved as a MultiStep Process That Predates the Whole Genome Duplication. PLoS One 8, e68734 (2013).

31. Pfeiffer, T. \& Morley, A. An evolutionary perspective on the Crabtree effect. Front. Mol. Biosci. 1, (2014).

32. Ibarra, R. U., Edwards, J. S. \& Palsson, B. O. Escherichia coli K-12 undergoes adaptive evolution to achieve in silico predicted optimal growth. Nature 420, 186-189 (2002).

33. Müller, S., Regensburger, G. \& Steuer, R. Enzyme allocation problems in kinetic metabolic networks: Optimal solutions are elementary flux modes. J. Theor. Biol. 347, 182-190 (2014).

34. Wortel, M. T., Peters, H., Hulshof, J. \& Teusink, B. Metabolic states with maximal specific rate carry flux through an elementary flux mode. 281, 1547-1555 (2014).

35. Basan, M. et al. Overflow metabolism in Escherichia coli results from efficient proteome allocation. Nature 528, 99104 (2015).

36. Nilsson, A. \& Nielsen, J. Metabolic Trade-offs in Yeast are Caused by F1F0-ATP synthase. Sci. Rep. 6, 22264 (2016).

37. Szenk, M., Dill, K. A. \& de Graff, A. M. R. R. Why Do Fast-Growing Bacteria Enter Overflow Metabolism? Testing the Membrane Real Estate Hypothesis. Cell Syst. 5, 95-104 (2017).

38. Long, C. P., Gonzalez, J. E., Feist, A. M., Palsson, B. O. \& Antoniewicz, M. R. Fast growth phenotype of E. coli K-12 from adaptive laboratory evolution does not require intracellular flux rewiring. Metab. Eng. 44, 100-107 (2017).

39. Piškur, J., Rozpedowska, E., Polakova, S., Merico, A. \& Compagno, C. How did Saccharomyces evolve to become a good brewer? Trends Genet. 22, 183-186 (2006).

40. Millard, P., Enjalbert, B., Uttenweiler-Joseph, S., Portais, J. C. \& Létisse, F. Control and regulation of acetate overflow in escherichia coli. Elife 10, 1-21 (2021).

41. Valgepea, K. et al. Systems biology approach reveals that overflow metabolism of acetate in Escherichia coli is triggered by carbon catabolite repression of acetyl-CoA synthetase. BMC Syst. Biol. 4, 166 (2010).

42. Kayser, A., Weber, J., Hecht, V. \& Rinas, U. Metabolic flux analysis of Escherichia coli in glucose-limited continuous culture. I. Growth-rate-dependent metabolic efficiency at steady state. Microbiology 151, 693-706 (2005).

43. Maclean, R. C. \& Gudelj, I. Resource competition and social conflict in experimental populations of yeast. 441, 498-501 (2006). 
44. Sigala, J.-C. et al. Physiological and transcriptional comparison of acetate catabolism between Acinetobacter schindleri ACE and Escherichia coli JM101. FEMS Microbiol. Lett. 366, (2019).

45. Deatherage, D. E. \& Barrick, J. E. Identification of mutations in laboratory-evolved microbes from next-generation sequencing data using breseq. Methods Mol. Biol. 1151, 165-188 (2014).

\section{Acknowledgements}

460 We would like to thank Vera Benavente, Tim van Wagensveld and Wouter W. Woud for

461 technical assistance. IR and FJB were financed by NWO-VIDI project 864.11.011.

\section{Author contribution}

464 IR, BT and HB conceived the study. IR carried out the experiments. AF re-sequenced evolved 465 strains. HB supervised the study. FJB and WG constructed mathematical models. IR, FJB and

466 HB analysed the data and wrote the paper. All authors read and commented on the manuscript.

\section{Conflict of interest}

469 HB is part-time employed by NIZO Food Research, a contract research organization. NIZO Food

470 Research had no role in the study design, data collection, and analysis, decision to publish, or 471 preparation of the manuscript. 
bioRxiv preprint doi: https://doi.org/10.1101/2021.05.24.445453; this version posted May 24, 2021. The copyright holder for this preprint (which

was not certified by peer review) is the author/funder, who has granted bioRxiv a license to display the preprint in perpetuity. It is made

Supplementary Information

available under aCC-BY 4.0 International license.

Selection for cell yield does not reduce overflow metabolism in E. coli

Rabbers et al.

\section{Supplementary Information}

$11{ }^{2}$ Department of Bioengineering, University of California, San Diego, La Jolla, CA, USA

$12{ }^{3}$ NIZO Food Research, Ede, The Netherlands

14 Keywords: overflow metabolism, $\mathrm{r} / \mathrm{k}$ selection, yield, emulsion culturing, metabolic strategy, cell size 
bioRxiv preprint doi: https://doi.org/10.1101/2021.05.24.445453; this version posted May 24, 2021. The copyright holder for this preprint (which

was not certified by peer review) is the author/funder, who has granted bioRxiv a license to display the preprint in perpetuity. It is made

Supplementary Information available under aCC-BY 4.0 International license.

Selection for cell yield does not reduce overflow metabolism in E. coli

Rabbers et al.

\section{Supplementary Information 1. Comparison of cell size under different growth conditions}

19 An underlying assumption in the hypothesis above is that the cell size after entering stationary phase when

20 growing on acetate is smaller than when entering stationary phase after growing on glucose. We found that

21 when wildtype cells are growing in a glucose limited batch culture where the final divisions are on the

22 overflow metabolite acetate, the cell size in stationary phase is approx. 55\% smaller than the cell size during

23 exponential growth on glucose. As strain MG1655 always produces acetate in a batch culture on glucose

24 investigating the entering of stationary phase without acetate exposure in batch culture is not possible. To

25 mimic the effects on cell size when going into stationary phase at a faster growth rate than on acetate we

26 prepared nitrogen limited batch cultures where no biphasic growth is observed. The results showed that the

27 final cell size after going into stationary phase with nitrogen limitation is approx. $24 \%$ smaller than during

28 exponential growth (see Supplementary Figure 4), which is significantly bigger than cells entering

29 stationary phase after growth on acetate.

30 A second assumption is that the growth rate reduction that comes with full respiration does not lead to a

31 cell size decrease that combined with its effect on increasing biomass yield would lead to a higher cell yield

32 than growth on acetate. We found 5 studies with $E$. coli where maximum growth rates and growth rates that

33 still allow full respiration are reported (see Supplementary Table 4). All five show that a growth rate

34 reduction to $77 \%-59 \%$ of the maximum growth rate is sufficient for a strain to change metabolism towards

35 full respiration. In our case the balanced growth rate on acetate is $28 \%$ and $31 \%$ of the maximum growth

36 rate for MG1655 and IR1 respectively. This is therefore well below the growth rate reduction required to

37 allow full respiration suggesting that the growth rate reduction on acetate as a substrate adds to the cell

38 number through making smaller cells. 
Supplementary Information

\section{Supplementary Information 2. Model description}

\section{Introduction}

The aim of this model is to evaluate the fitness of biphasic metabolism, incl. overflow metabolism, and compare it to the fitness of a pure-respiration strategy; to identify which parameters determine the winning metabolic strategy, i.e. the one favoured by evolution when cells are confronted with a finite amount of sugar that they can consume until its depletion.

We assume that the cells deplete a finite amount of sugar. This sugar amount limits the final number of produced cells, as all other nutrients are assumed in excess. Selection of cell number yield takes place when single cells are allowed to grow, while they are physically separated in emulsion droplets containing glucose-limited medium. In this scenario the total time of growth does not matter. Selection of growth rate occurs in a well-mixed environment in a batch culture, also until all carbon sources have been depleted. In

51 both cases, the winning evolutionary strategy made the most offspring after all carbon sources, i.e. the limiting nutrients, have been depleted (sugar and overflow metabolites).

\section{Model equations}

The number of cells made from a finite starting amount of glucose, $g l c[0]$, when a fraction $\phi$ of the glucose uptake rate goes to acetate formation equals,

$$
\underbrace{\Delta N_{g}}_{\text {cells }}=\underbrace{\frac{1}{\rho}}_{\frac{\text { cell }}{V_{\text {liter }}} \frac{1}{V_{\text {gram }}}} \underbrace{Y_{\text {ral }}^{Y_{x / g}}}_{\text {liter }}(1-\phi) \underbrace{\text { glc }[0]}_{\text {mol }} \text { and } 0 \leq \phi \leq 1,
$$

with the units of each factor explicitly indicated: $V_{c, g}=$ the volume of a single cell during growth on glucose, $\rho=$ the mass density, and $Y_{x / g}=$ the gram biomass yield on glucose. Note that no cells are made when all glucose, during the glucose phase, is converted into acetate (i.e. $\phi=1$ ). After the glucose growth period, with duration $T_{g}$, during which $\Delta N_{g}$ cells were made, the total number of cells equals,

$$
N\left[T_{g}\right]=\Delta N_{g}+N[0]=e^{\mu_{g}[\phi] T_{g}} N[0],
$$

with $N[0]$ as the starting number of cells, such that

$$
\Delta N_{g}=\left(e^{\mu_{g}[\phi] T_{g}}-1\right) N[0] \text { and } T_{g}=\frac{1}{\mu_{g}[\phi]} \ln \left[\frac{\Delta N_{g}}{N[0]}+1\right]
$$


Supplementary Information

Selection for cell yield does not reduce overflow metabolism in E. coli

Rabbers et al.

64 The function $\mu_{g}[\phi]$ denotes the growth rate during the glucose phase and is dependent on the fraction $\phi$ 65 of glucose converted into acetate. Chemostat experiments indicate that fully respiring cells, with $\phi=0$, 66 grow slower than partially-overflowing cells with $\phi \approx 0.2$. And, cells that only overflow, i.e. $\phi=1$, clearly 67 do not grow on glucose at all. The dependency of the growth rate on glucose on $\phi$, i.e. $\mu_{g}[\phi]$, therefore 68 has to obey the following experimental observations:

69 1. when $\phi=0$, it equals the growth rate at pure respiration, $\mu_{g}[0]=\alpha \mu_{a}$, which exceeds $\mu_{a}$ (the growth 70 rate on acetate); thus, $\alpha>1$, as a fully respiring cell growing on glucose grows faster than a cell growing 71 on acetate (given chemostat and batch data).

72. at $\phi=1$, the growth rate on glucose equals 0 as all glucose is converted into acetate.

73 3. a $\phi$-value $\phi_{\text {peak }}$ exists, $0<\phi_{\text {peak }}<1$, with a growth rate $\mu_{g}\left(\phi_{\text {peak }}\right)$ that exceeds the growth rate at 74 pure respiration $\alpha \mu_{a}$ (and $\mu_{a}$ ).

75 Thus, the function $\mu_{g}[\phi]$ rises from a nonzero starting value $\mu_{g}[0]>\mu_{a}>0$ to a maximal value at $76 \mu_{g}\left[\phi_{\text {peak }}\right]$ and then decreases again to 0 at $\mu_{g}[1]$. This behavior is an extrapolation of experimental data.

77 The following function for the growth rate on glucose suits our purposes (with the Greek letters denoted positive parameters),

$$
\mu_{g}[\phi]=(1-\phi)\left(\alpha+\delta e^{-\frac{(\beta-\phi)^{2}}{\gamma^{2}}}\right)
$$

which equals zero at $\phi=1$ and is positive at $\phi=0$ where its value equals $\alpha \mu_{a}$. Note that this function shows the desired behavior, but is otherwise arbitrary.

The amount of acetate produced during the glucose growth period equals,

$$
\underbrace{\operatorname{ace}\left[T_{g}\right]}_{\text {mol acetate }}=\underbrace{Y_{a / g}}_{\frac{\text { molacetate }}{\text { mol glucose }}} \phi \underbrace{g l c[0]}_{\text {mol }} .
$$

The number of cells that we can make from this amount of acetate equals,

$$
\underbrace{\Delta N_{a}}_{\text {cells }}=\underbrace{\frac{1}{\text { liter }}}_{\frac{\text { cell }}{\text { liter }} \frac{1}{V_{c, a}}} \underbrace{Y_{x / a}}_{\frac{\text { gram }}{\text { mol }}} \underbrace{\text { ace }\left[T_{g}\right]}_{\text {mol acetate }},
$$

with $V_{c, a}$ as the volume of a cell during growth on acetate and the $Y_{x / a}$ as the gram biomass yield on acetate.

87 (Note that we neglect that from glucose-grown cells, more cells can be made than expected from the acetate 
Supplementary Information

Selection for cell yield does not reduce overflow metabolism in E. coli

Rabbers et al.

yield and acetate amount, because glucose-grown cells are larger than acetate cells (see main text). This effect we neglect in the model, to keep it simple.)

Thus, the number of cells at the end of the experiments, after glucose and acetate growth, equals

$$
N\left[T_{a}+T_{g}\right]=\Delta N_{a}+N\left[T_{g}\right] \quad \text { and } N\left(T_{a}+T_{g}\right)=e^{\mu_{a} T_{a}} N\left[T_{g}\right],
$$

with $T_{a}$ as the duration of the acetate growth period and $\mu_{a}$ as the growth rate on acetate. These last two equations allow us to determine the growth period on acetate,

$$
T_{a}=\frac{1}{\mu_{a}} \ln \left[\frac{\Delta N_{a}}{N\left[T_{g}\right]}+1\right]
$$

The total number of cells made from the starting amount of glucose equals,

$$
N\left[T_{g}+T_{a}\right]=e^{\mu_{a} T_{a}} e^{\mu_{g}[\phi] T_{g}} N[0] .
$$

The total number of cells made equals $\Delta N=N\left[T_{g}+T_{a}\right]-N[0]$.

We define the growth factor as

$$
G\left[\phi, V_{c, a}, V_{c, g}\right]:=\frac{N\left[T_{g}+T_{a}\right]}{N[0]}=e^{\mu_{a} T_{a}} e^{\mu_{g}[\phi] T_{g}} .
$$

and the geometric fitness as

$$
F\left[\phi, V_{c, a}, V_{c, g}\right]:=\frac{\ln G}{T_{g}+T_{a}}=\mu_{g}[\phi] \frac{T_{g}}{T_{g}+T_{a}}+\mu_{a} \frac{T_{a}}{T_{g}+T_{a}}
$$

which equals the time-averaged growth rate, since $\frac{T_{g}}{T_{g}+T_{a}}$ equals the fraction of time spent in phase 1 (glucose phase) and $\frac{T_{a}}{T_{g}+T_{a}}$ equals the fraction of time spent in the acetate phase. The $F\left[\phi, V_{c, a}, V_{c, g}\right]$ is plotted in Figure 2C.

\section{A complication: cell size and growth rate are related for $E$. coli}

E. coli has a fixed DNA replication time. This means that at long generation times (low growth rates) enough time exists between cell birth and division to replicate a single copy of DNA. This is not the case when the generation time is shorter than the DNA replication time: then DNA replication occurs continuously throughout the cell cycle and cells have started replication of DNA copies for future progeny. 
bioRxiv preprint doi: https://doi.org/10.1101/2021.05.24.445453; this version posted May 24, 2021. The copyright holder for this preprint (which

was not certified by peer review) is the author/funder, who has granted bioRxiv a license to display the preprint in perpetuity. It is made

Supplementary Information available under aCC-BY 4.0 International license.

Selection for cell yield does not reduce overflow metabolism in E. coli

Rabbers et al.

111 As a result, cells that grow fast have multiple origins of replication. It has been shown that the exponential

112 relation between cell size and growth rate can be understood to result from the fact that $E$. coli maintains a

113 constant ratio of cell size over the number of origins of replication. What matters for our model is that wild

114 type cells obey the following relation: $V(\mu)=V(0) e^{\varepsilon \mu}$ with $V(0)=0.28 \mu m^{3}$ and $\gamma=1.33 h r^{1}$.

115 Table. The used parameters for Figure 2.

\begin{tabular}{|l|l|}
\hline Name & Value \\
\hline Cell density & $280 \times 10^{-15} \mathrm{~g} / \mu \mathrm{m}^{3}$ \\
\hline Biomass yield on glucose & $88 \mathrm{~g} / \mathrm{mol}$ \\
\hline Biomass yield on acetate & $20 \mathrm{~g} / \mathrm{mol}$ \\
\hline Acetate yield on glucose & $2 \mathrm{~mol} / \mathrm{mol}$ \\
\hline Cell volume on glucose $(\mathrm{Vc}, \mathrm{g})$ & $1 \mu \mathrm{m}^{3}$ \\
\hline Cell volume on acetate $(\mathrm{Vc}, \mathrm{a})$ & $0.5 \mu \mathrm{m}^{3}$ \\
\hline Growth rate on glucose $(\mu \mathrm{g})$ & $1 \mathrm{hr}^{-1}$ \\
\hline Growth rate on acetate $(\mu \mathrm{a})$ & $0.3 \mathrm{hr}^{-1}$ \\
\hline$\alpha$ & 0.2 \\
\hline$\beta$ & 0.5 \\
\hline$\gamma$ & 0.4 \\
\hline & 2 \\
\hline
\end{tabular}

116

117 
bioRxiv preprint doi: https://doi.org/10.1101/2021.05.24.445453; this version posted May 24, 2021. The copyright holder for this preprint (which was not certified by peer review) is the author/funder, who has granted bioRxiv a license to display the preprint in perpetuity. It is made

Supplementary Information available under aCC-BY 4.0 International license.

Selection for cell yield does not reduce overflow metabolism in E. coli

Rabbers et al.

\section{Supplementary Figures}

119

120

121

122

123

124

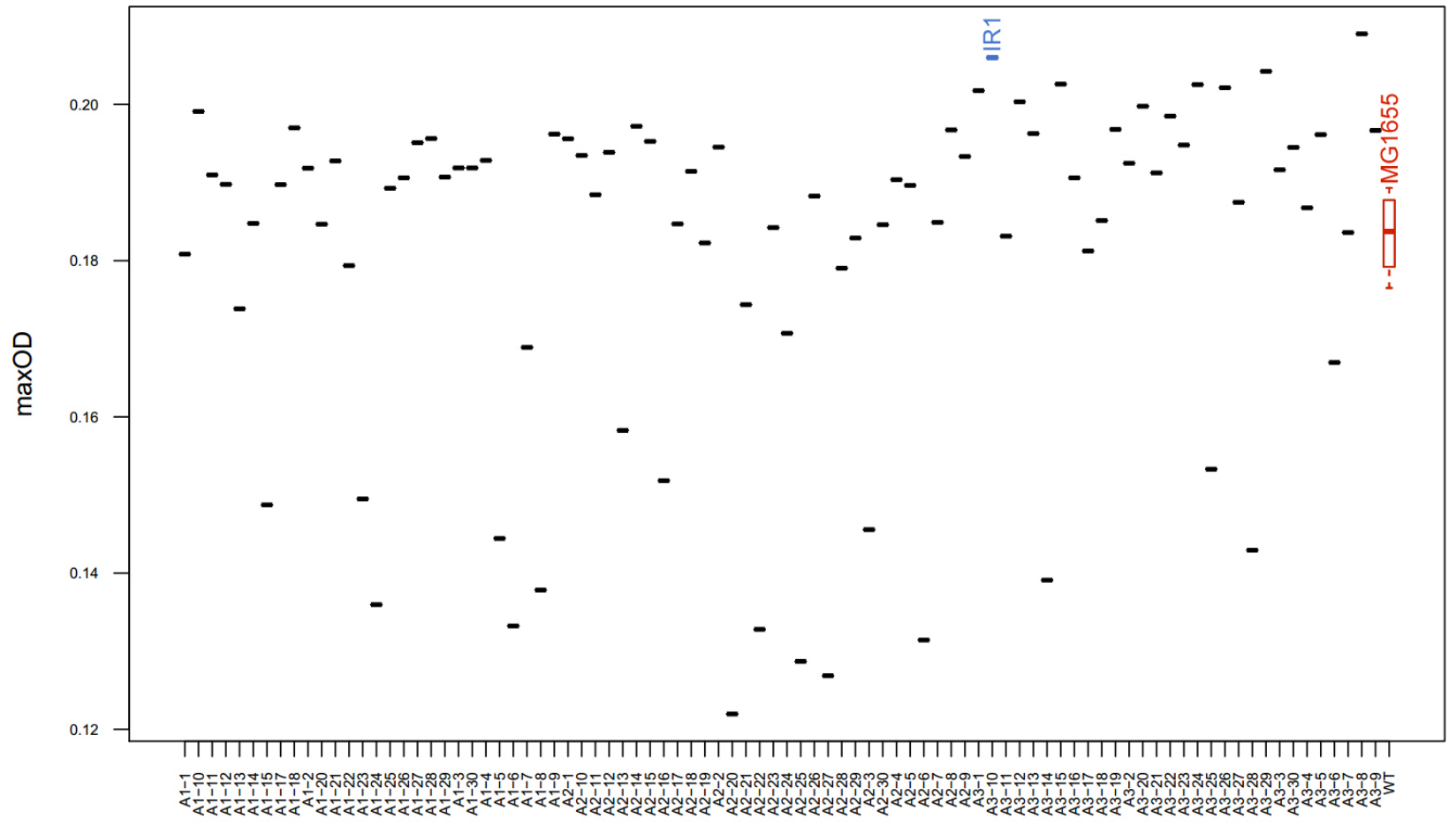

Strain

Supplementary Figure 1: After 53 propagations in emulsion, three replicate populations A1, A2 and A3 were plated, and 90 single colonies were picked. The maximal optical densities at 600nm of these evolved strains were compared to that of the wildtype (boxplot of 6 replicates), to screen for strains with a suspected increase in yield. Strain IRI was selected for extensive characterization based on the initial screening measurements. 
bioRxiv preprint doi: https://doi.org/10.1101/2021.05.24.445453; this version posted May 24, 2021. The copyright holder for this preprint (which was not certified by peer review) is the author/funder, who has granted bioRxiv a license to display the preprint in perpetuity. It is made Supplementary Information available under aCC-BY 4.0 International license.

Selection for cell yield does not reduce overflow metabolism in E. coli Rabbers et al.

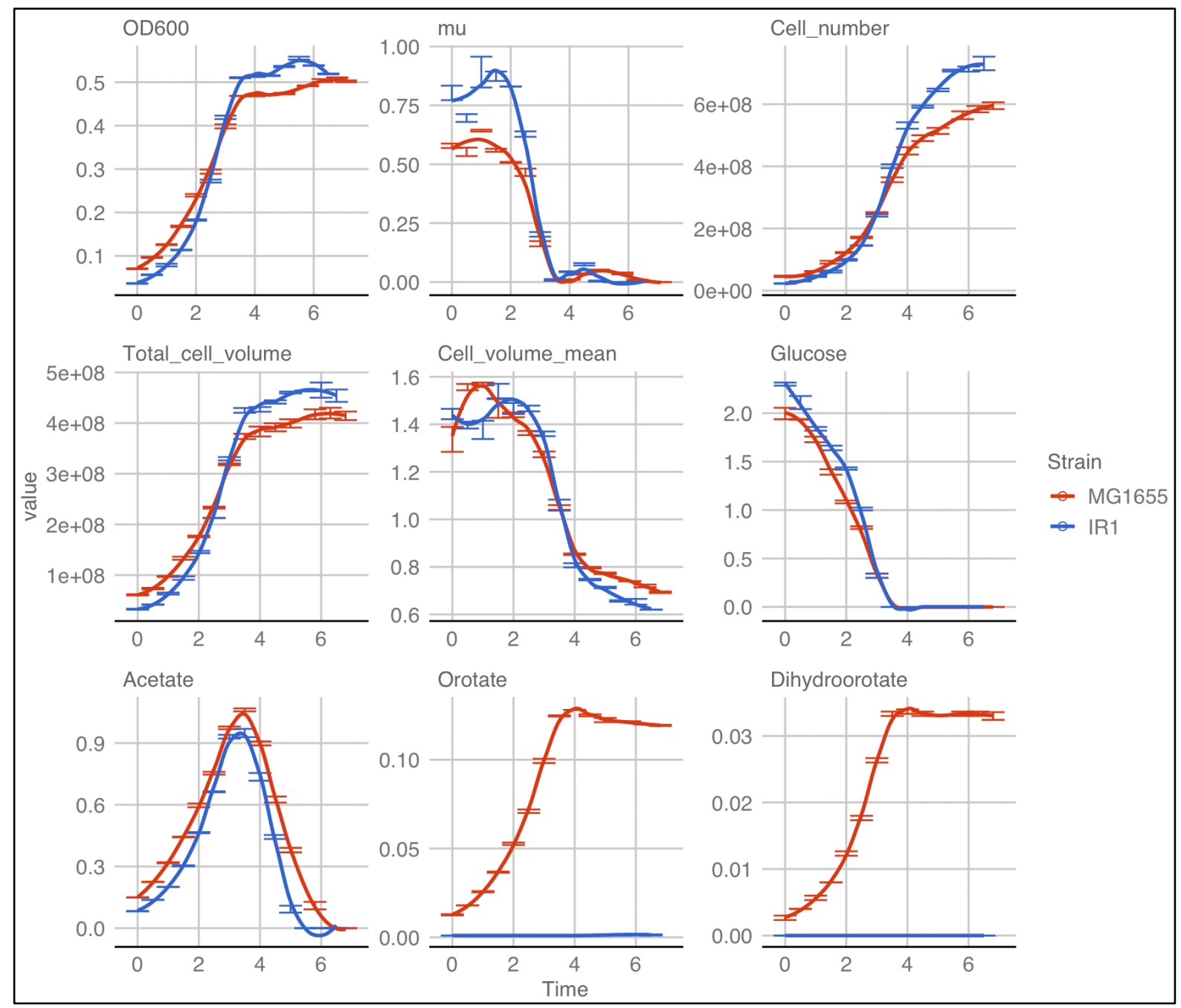

125

126

127

128

129

130

Supplementary Figure 2: Growth characteristics from batch cultures. Units: Growth rate mu [h-1], Cell_number [number/ml culture], Total_cell_volume $\left[\mu \mathrm{m}^{3} / \mathrm{ml}\right.$ culture], Cell_volume_mean $\left[\mu \mathrm{m}^{3}\right]$, Glucose [mM], Acetate [mM], Orotate [mM], Dihydroorotate [mM]. Error bars are standard errors of the mean, $n=3$. For completenes the panels from Fig 1 C-E (main text) are shown here as well. 
bioRxiv preprint doi: https://doi.org/10.1101/2021.05.24.445453; this version posted May 24, 2021. The copyright holder for this preprint (which was not certified by peer review) is the author/funder, who has granted bioRxiv a license to display the preprint in perpetuity. It is made Supplementary Information available under aCC-BY 4.0 International license.

Selection for cell yield does not reduce overflow metabolism in E. coli

Rabbers et al.

131
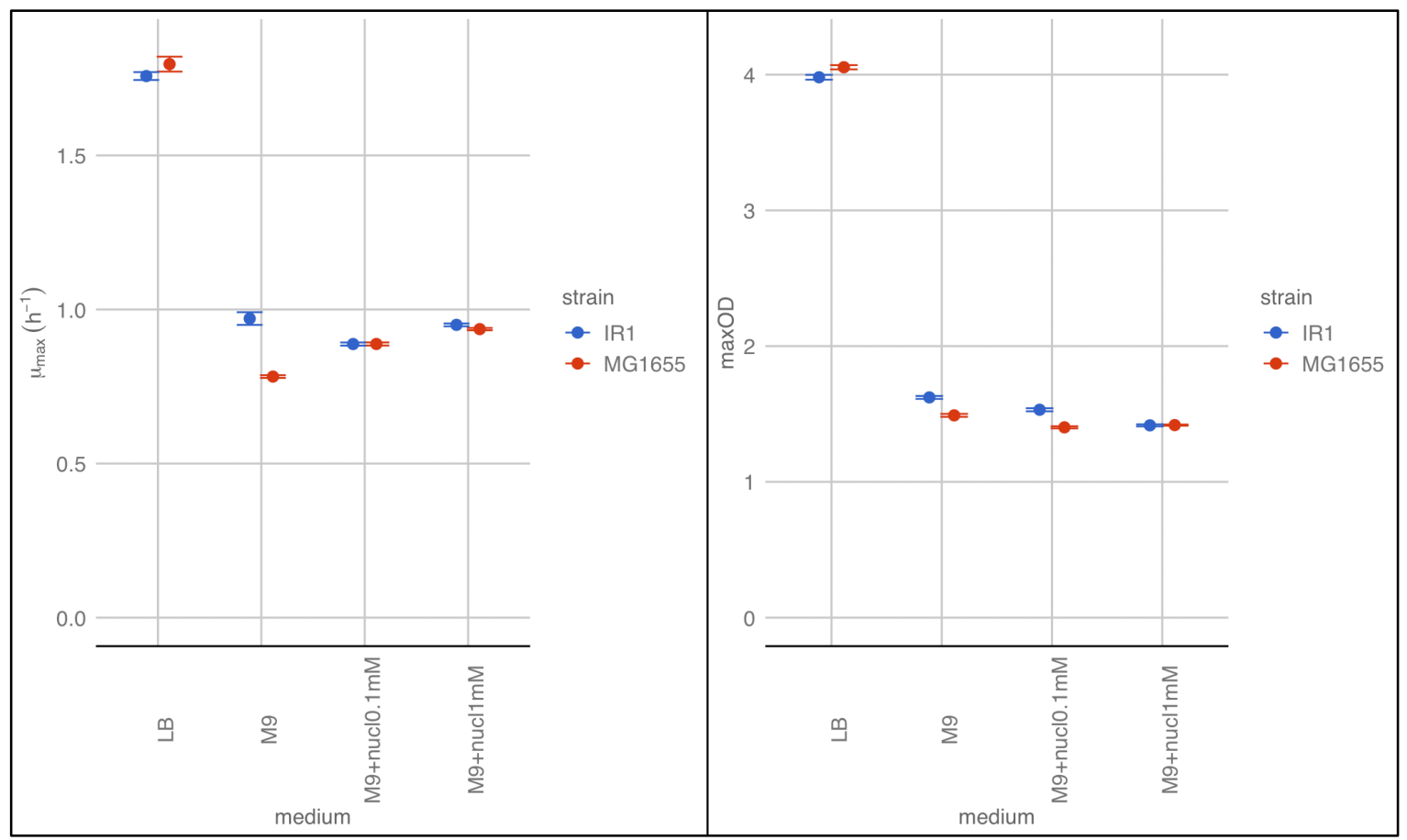

132 Supplementary Figure 3. Phenotypic properties of the wild type strain and IR1. Phenotypes associated with a mutation in the rph-

133 pyrE region that strain IR1 acquired when evolved on M9 minimal medium, is consistent with an earlier described medium

134 adaptation ${ }^{2-5}$. On rich LB medium the ancestral wildtype strain has a higher maximal specific growth rate ( $\left.\mu_{\text {max }}\right)$ and final optical

135 density (maxOD) than strain IR1. When grown on M9 medium however, the pyrimidine production deficiency of the wildtype strain

136 leads to a reduced $\mu_{\max }$ and maxOD. If the minimal medium is supplemented with free nucleotides (0.1 or 1 mM), this disadvantage

137 of the wildtype strain is alleviated. Means with SEM are shown, $n=6$.

138 
bioRxiv preprint doi: https://doi.org/10.1101/2021.05.24.445453; this version posted May 24, 2021. The copyright holder for this preprint (which was not certified by peer review) is the author/funder, who has granted bioRxiv a license to display the preprint in perpetuity. It is made Supplementary Information available under aCC-BY 4.0 International license.

Selection for cell yield does not reduce overflow metabolism in E. coli Rabbers et al.

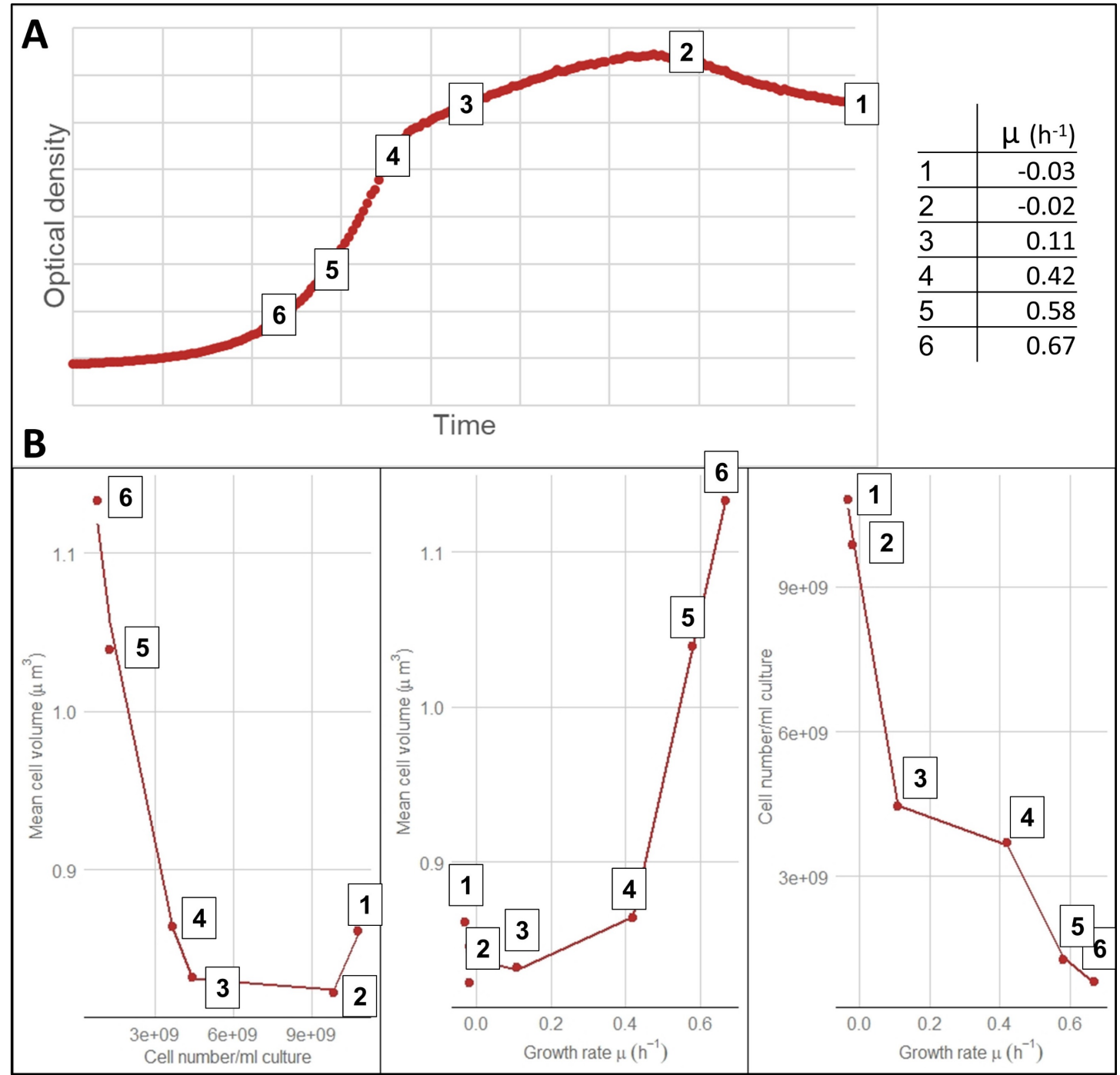

Supplementary Figure 4: A. Wild type MG1655 was grown in batch on M9 supplemented with 50 mM glucose. In this case the growth medium is nitrogen limited instead of carbon limited hence cells still grow on glucose when going into stationary phase (no growth on acetate). Using a dilution series of different inoculation densities samples were taken at various timepoints throughout the growth curve for Coulter Counter measurements (i.e. cell volume and cell number). The growth rate (slope of $\log (O D))$ was determined for different timepoints from mid-exponential to prolonged stationary phase. $\boldsymbol{B}$. As the growth rate decreases, the cell volume also decreases while the cell number increases. In this nitrogen limited experiment, the decrease in cell volume from mid-exponential until stationary phase is around $24 \%$. This decrease is significantly less than a decrease in cell volume of 55\% observed for cells that become stationary in a glucose limited culture where a second growth phase on acetate occurs - see Supplemental Figure 2). Data was fitted with a smooth spline (smoothing parameter 0.3), $n=2$. 
bioRxiv preprint doi: https://doi.org/10.1101/2021.05.24.445453; this version posted May 24,2021 . The copyright holder for this preprint (which was not certified by peer review) is the author/funder, who has granted bioRxiv a license to display the preprint in perpetuity. It is made

Supplementary Information available under aCC-BY 4.0 International license.

\section{Supplementary Tables}

151 Supplementary Table 1: Overview of the phenotypic characterization from wild type MG1655 and evolved strain IR1. Mean and 152 standard deviation are given $(n=3)$. Growth rates and maximal ODs were measured in shake flask (SF), as well as microplate 153 (MP). All other measures come from the shake flask cultures. The second growth phase on acetate is too short to reach balanced 154 growth, and sample handling for shake flasks can lead to some temperature reduction, which can cause a reduction in apparent 155 growth rates. The growth rate difference between the wild type and evolved strain were therefore confirmed using microplate 156 growth curves to ensure balanced growth conditions.

\begin{tabular}{|c|c|c|c|c|c|c|}
\hline & \multicolumn{2}{|c|}{ MG1655 } & \multicolumn{2}{|c|}{ IR1 } & \multirow{2}{*}{$\begin{array}{l}\text { IR1 \% } \\
\text { of } \\
\text { MG1655 }\end{array}$} & \multirow{2}{*}{$\begin{array}{l}\text { t-test (p- } \\
\text { value) }\end{array}$} \\
\hline & mean & st.dev. & mean & st.dev. & & \\
\hline cell number/ml culture & $5.95 \mathrm{E}+08$ & $1.93 \mathrm{E}+07$ & $7.31 \mathrm{E}+08$ & $3.77 \mathrm{E}+07$ & 123 & 0.0117 \\
\hline glc exp cell volume $\left(\mu \mathrm{m}^{3}\right)$ & 1.57 & 0.01 & 1.54 & 0.05 & 98 & 0.4449 \\
\hline stationary cell volume $\left(\mu \mathrm{m}^{3}\right)$ & 0.70 & 0.01 & 0.62 & 0.00 & 89 & 0.0002 \\
\hline total cell volume $/ \mathrm{ml}$ culture & $4.14 \mathrm{E}+08$ & $1.44 \mathrm{E}+07$ & $4.54 \mathrm{E}+08$ & $2.12 \mathrm{E}+07$ & 110 & 0.0615 \\
\hline dry weight (mg/ml culture) & 0.163 & 0.006 & 0.181 & 0.006 & 111 & 0.0208 \\
\hline $\begin{array}{l}\text { total protein content }(\mu \mathrm{g} / \mathrm{ml} \\
\text { culture) }\end{array}$ & 306.0 & 8.5 & 345.4 & 10.2 & 113 & 0.0000 \\
\hline maximal $\mathrm{OD}_{600}-\mathrm{SF}$ & 0.510 & 0.002 & 0.555 & 0.006 & 109 & 0.0027 \\
\hline $\begin{array}{l}\text { maximal specific growth rate } \\
\text { glc }\left(\mu_{\max }\left(h^{-1}\right)\right)-S F\end{array}$ & 0.579 & 0.010 & 0.805 & 0.008 & 139 & 0.0000 \\
\hline $\begin{array}{l}\text { maximal specific growth rate } \\
\text { acet }\left(\mu_{\max }\left(\mathrm{h}^{-1}\right)\right) \text { during } 2 \text { nd } \\
\text { growth phase - SF }\end{array}$ & 0.034 & 0.001 & 0.056 & 0.008 & 166 & 0.0359 \\
\hline maximal $\mathrm{OD}_{600}-\mathrm{MP}$ & 0.531 & 0.013 & 0.570 & 0.008 & 107 & 0.0154 \\
\hline $\begin{array}{l}\text { maximal specific growth rate } \\
\operatorname{glc}\left(\mu_{\max }\left(h^{-1}\right)\right) \text { - MP }\end{array}$ & 0.839 & 0.015 & 1.100 & 0.005 & 131 & 0.0003 \\
\hline $\begin{array}{l}\text { maximal specific growth rate } \\
\text { acet }\left(\mu_{\max }\left(h^{-1}\right)\right) \text { balanced } \\
\text { growth - MP }\end{array}$ & 0.224 & 0.007 & 0.294 & 0.011 & 131 & 0.0017 \\
\hline $\begin{array}{l}\text { fraction of } \mathrm{C} \text { to acetate (end of } \\
1 \text { st growth phase) }\end{array}$ & 0.159 & 0.005 & 0.150 & 0.003 & 94 & 0.0690 \\
\hline $\begin{array}{l}\text { fraction of } \mathrm{C} \text { to pyrimidine } \\
\text { intermediates (end of 2nd } \\
\text { growth phase) }\end{array}$ & 0.051 & 0.001 & 0.000 & 0.000 & 1 & 0.0000 \\
\hline
\end{tabular}


bioRxiv preprint doi: https://doi.org/10.1101/2021.05.24.445453; this version posted May 24, 2021. The copyright holder for this preprint (which was not certified by peer review) is the author/funder, who has granted bioRxiv a license to display the preprint in perpetuity. It is made

Supplementary Information available under aCC-BY 4.0 International license.

158

159

160

Supplementary Table 2: Strain IR1 was propagated for 25 additional cycles in emulsion, and 15 strains (3 per replicate evolution

Selection for cell yield does not reduce overflow metabolism in E. coli

Rabbers et al.

\section{culture) were screened for acetate production after 3, 4 or 5 hours of batch growth. All strains still produced considerable amounts}

of acetate indicating that overflow metabolism was still present.

\begin{tabular}{|c|c|c|c|c|c|c|c|c|c|}
\hline Strain & $\begin{array}{l}\text { Acetate }(\mathrm{n} \\
\text { time }=3 \mathrm{~h}\end{array}$ & $\begin{array}{l}\mathrm{nM}) \\
\text { time }=4 \mathrm{~h}\end{array}$ & time $=5 \mathrm{~h}$ & $\begin{array}{l}\text { OD600 } \\
\text { time }=3 \mathrm{~h}\end{array}$ & time $=4 \mathrm{~h}$ & time $=5 \mathrm{~h}$ & $\begin{array}{l}\text { Acetate } / C \\
\text { time }=3 \mathrm{~h}\end{array}$ & $\begin{array}{l}\mathrm{D} \\
\text { time }=4 \mathrm{~h}\end{array}$ & time $=5 \mathrm{~h}$ \\
\hline $\mathrm{A} 1-\mathrm{C} 2$ & 0.549 & 0.946 & & 0.157 & 0.370 & 0.513 & 3.50 & 2.56 & \\
\hline A1-F5 & 0.528 & 0.912 & & 0.152 & 0.323 & 0.509 & 3.47 & 2.82 & \\
\hline A1-D5 & 0.554 & 0.969 & & 0.158 & 0.347 & 0.507 & 3.51 & 2.79 & \\
\hline A1-F6 & 0.537 & 0.934 & & 0.154 & 0.320 & 0.507 & 3.49 & 2.92 & \\
\hline A1-E6 & 0.536 & 0.959 & & 0.156 & 0.339 & 0.509 & 3.44 & 2.83 & \\
\hline A2-B6 & 0.736 & 1.237 & & 0.223 & 0.528 & 0.530 & 3.30 & 2.34 & \\
\hline A2-D5 & 0.725 & 1.327 & & 0.205 & 0.495 & 0.506 & 3.54 & 2.68 & \\
\hline A2-E9 & 0.648 & 1.258 & & 0.196 & 0.464 & 0.490 & 3.31 & 2.71 & \\
\hline A2-E6 & & 0.847 & 1.278 & 0.105 & 0.264 & 0.514 & & 3.21 & 2.49 \\
\hline A2-G7 & 0.745 & 1.316 & & 0.210 & 0.503 & 0.522 & 3.55 & 2.62 & \\
\hline A3-E7 & 0.568 & 1.03 & & 0.173 & 0.370 & 0.505 & 3.28 & 2.78 & \\
\hline A3-G11 & 0.594 & 1.099 & & 0.177 & 0.401 & 0.495 & 3.36 & 2.74 & \\
\hline A3-D12 & 0.695 & 1.313 & & 0.213 & 0.465 & 0.492 & 3.26 & 2.82 & \\
\hline A3-B12 & 0.86 & 1.247 & & 0.249 & 0.530 & 0.523 & 3.45 & 2.35 & \\
\hline A3-G12 & & 0.791 & 1.286 & 0.095 & 0.241 & 0.482 & & 3.28 & 2.67 \\
\hline MG1655 & 0.441 & 0.733 & 1.091 & 0.114 & 0.198 & 0.327 & 3.87 & 3.70 & 3.34 \\
\hline IR1 & 0.572 & 1.068 & & 0.176 & 0.378 & 0.505 & 3.25 & 2.83 & \\
\hline
\end{tabular}

161 
bioRxiv preprint doi: https://doi.org/10.1101/2021.05.24.445453; this version posted May 24, 2021. The copyright holder for this preprint (which

was not certified by peer review) is the author/funder, who has granted bioRxiv a license to display the preprint in perpetuity. It is made

Supplementary Information available under aCC-BY 4.0 International license.

Selection for cell yield does not reduce overflow metabolism in E. coli

Rabbers et al.

\begin{tabular}{|c|c|c|c|c|}
\hline position & mutation & annotation & gene & description \\
\hline $2,760,454$ & $\mathrm{C} \rightarrow \mathrm{A}$ & $\begin{array}{l}\text { intergenic } \\
(+60 /-93)\end{array}$ & yfjI $\rightarrow / \rightarrow$ yfjJ & $\begin{array}{l}\text { CP4-57 prophage; uncharacterized } \\
\text { protein/CP4-57 prophage; uncharacterized } \\
\text { protein }\end{array}$ \\
\hline $2,999,264$ & $\mathrm{G} \rightarrow \mathrm{A}$ & $\begin{array}{l}\mathrm{Q} 210^{*}(\underline{\mathrm{CA}} \\
\mathrm{A} \rightarrow \underline{\mathrm{TAA}})\end{array}$ & ygeR $\leftarrow$ & $\begin{array}{l}\text { LytM domain-containing M23 family } \\
\text { putative peptidase; septation lipoprotein }\end{array}$ \\
\hline $3,026,033$ & $\Delta 1 \mathrm{bp}$ & $\begin{array}{l}\text { coding }(268 \\
/ 1320 \mathrm{nt})\end{array}$ & guaD $\rightarrow$ & guanine deaminase \\
\hline $3,815,859$ & $\Delta 82 \mathrm{bp}$ & $\begin{array}{l}\text { pseudogene } \\
(610-691 \quad / \\
716 \mathrm{nt})\end{array}$ & $\mathrm{rph} \leftarrow \mathrm{pyrE}$ & $\begin{array}{l}\text { ribonuclease PH (defective); enzyme; } \\
\text { degradation of RNA; RNase PH }\end{array}$ \\
\hline $3,984,420$ & $\mathrm{~T} \rightarrow \mathrm{A}$ & $\begin{array}{l}\mathrm{T} 530 \mathrm{~S}(\underline{\mathrm{AC}} \\
\mathrm{C} \rightarrow \underline{\mathrm{TCC}})\end{array}$ & $\operatorname{asl} \mathrm{A} \leftarrow$ & $\begin{array}{l}\text { putative Ser-type periplasmic non-aryl } \\
\text { sulfatase }\end{array}$ \\
\hline
\end{tabular}

163 
bioRxiv preprint doi: https://doi.org/10.1101/2021.05.24.445453; this version posted May 24, 2021. The copyright holder for this preprint (which was not certified by peer review) is the author/funder, who has granted bioRxiv a license to display the preprint in perpetuity. It is made Supplementary Information available under aCC-BY 4.0 International license.

Selection for cell yield does not reduce overflow metabolism in E. coli

Rabbers et al.

\begin{tabular}{|c|c|c|c|c|c|c|c|}
\hline Reference & $\begin{array}{l}\text { Figure } \\
\text { /table }\end{array}$ & Strain & $\begin{array}{l}\text { Culture } \\
\text { method }\end{array}$ & Medium & $\begin{array}{l}\mu \text { at which } \\
\text { cells still } \\
\text { show full } \\
\text { respiration }\end{array}$ & $\begin{array}{c}\mu_{\max } \\
/ \text { highest } \\
\text { D used } \\
\text { in paper }\end{array}$ & $\begin{array}{c}\text { Fraction } \\
\text { of } \mu_{\max } \text { at } \\
\text { which } \\
\text { cells still } \\
\text { show full } \\
\text { respiratio } \\
n\end{array}$ \\
\hline $\begin{array}{l}\text { Nanchen } \\
(2006)^{6}\end{array}$ & Fig. 3 & $\begin{array}{l}\text { MG1655 (1- F- } \\
\text { rph-1Fnr+; } \\
\text { DSMZ) }\end{array}$ & chemostat & $\begin{array}{c}\text { M9 } \\
\text { minimal }\end{array}$ & 0.4 & 0.7 & 0.57 \\
\hline $\begin{array}{l}\text { Holms } \\
(1996)^{7}\end{array}$ & $\begin{array}{c}\text { Table } \\
7\end{array}$ & $\begin{array}{c}\text { ML308 = } \\
\text { ATCC15224 }\end{array}$ & chemostat & & 0.72 & 0.94 & 0.77 \\
\hline $\begin{array}{l}\text { Valgepea } \\
(2010)^{8}\end{array}$ & Fig. 2 & $\begin{array}{l}\text { K12 MG1655 } \\
(1-\text { F- rph- } \\
\text { 1Fnr+; DSMZ) }\end{array}$ & chemostat & $\begin{array}{l}\text { defined } \\
\text { minimal }\end{array}$ & 0.27 & 0.46 & 0.59 \\
\hline $\begin{array}{l}\text { Renilla } \\
(2012)^{9}\end{array}$ & Fig 4 & $\begin{array}{c}\text { BW25113 a } \\
\text { K12-derivative }\end{array}$ & chemostat & $\begin{array}{l}\text { defined } \\
\text { minimal }\end{array}$ & 0.5 & 0.7 & 0.71 \\
\hline $\begin{array}{l}\text { Meyer } \\
(1984)^{10}\end{array}$ & Fig. 1 & $\begin{array}{l}\text { defined } \\
\text { medium }\end{array}$ & chemostat & & 0.35 & 0.54 & 0.65 \\
\hline \multirow[t]{2}{*}{$\begin{array}{c}\text { Basan } \\
(2015)^{11}\end{array}$} & Fig. 1 & $\mathrm{~K} 12=\mathrm{MG} 1655$ & batch & minimal & 0.76 & 1.26 & 0.60 \\
\hline & & & & & $\begin{array}{l}\mu_{\max } \text { on } \\
\text { acetate }\end{array}$ & $\begin{array}{l}\mu_{\max } \text { on } \\
\text { glucose }\end{array}$ & $\begin{array}{c}\text { Fraction } \\
\text { of } \mu_{\max }\end{array}$ \\
\hline $\begin{array}{l}\text { This } \\
\text { Study }\end{array}$ & & MG1655 & batch & $\begin{array}{c}\text { M9 } \\
\text { minimal }\end{array}$ & 0.22 & 0.84 & 0.26 \\
\hline $\begin{array}{l}\text { This } \\
\text { Study }\end{array}$ & & IR1 - evolved & batch & $\begin{array}{c}\text { M9 } \\
\text { minimal }\end{array}$ & 0.29 & 1.1 & 0.26 \\
\hline
\end{tabular}


bioRxiv preprint doi: https://doi.org/10.1101/2021.05.24.445453; this version posted May 24,2021. The copyright holder for this preprint (which was not certified by peer review) is the author/funder, who has granted bioRxiv a license to display the preprint in perpetuity. It is made

Supplementary Information available under aCC-BY 4.0 International license.

Selection for cell yield does not reduce overflow metabolism in E. coli

Rabbers et al.

168

169

170

\begin{tabular}{|c|c|c|c|c|}
\hline Organism & $\mu$ on acetate & $\mu$ on glc & $\mu_{\mathrm{ac}} / \mu_{\mathrm{glc}}$ & Reference \\
\hline E. coli MG1655 & 0.22 & 0.84 & 0.28 & This study \\
\hline E. coli IR1 & 0.29 & 1.10 & 0.31 & This study \\
\hline Yarrowia lipolytica & 0.28 & 0.41 & 0.68 & Robak $(2007)^{12}$ \\
\hline Corynebacterium glutamicum & 0.28 & 0.32 & 0.88 & Wendisch et al. $(2000)^{13}$ \\
\hline Rhodobacter capsulatus & 0.29 & $0.42^{\mathrm{a}}$ & 0.71 & Willison $(1988)^{14}$ \\
\hline E. coli $\mathrm{B} / \mathrm{r}$ strain NF790 & 0.30 & 0.89 & 0.34 & Andersen\&Meyenburg $(1980)^{15}$ \\
\hline S. cerevisiae AG1-7 & 0.12 & 0.31 & 0.39 & Johnston et al. $(1979)^{16}$ \\
\hline E. coli BW25113 & 0.29 & 0.60 & 0.48 & Volkmer\&Heinemann $(2011)^{17}$ \\
\hline Neurospora crassa & 0.41 & 0.51 & 0.80 & Alberghina et al. $(1975)^{18}$ \\
\hline Acinetobacter schindleri ${ }^{\mathrm{b}}$ & 0.91 & & & Sigala $(2019)^{19}$ \\
\hline
\end{tabular}

Supplementary Table 5: Growth rates on acetate and glucose, and the ratio between them for a number of

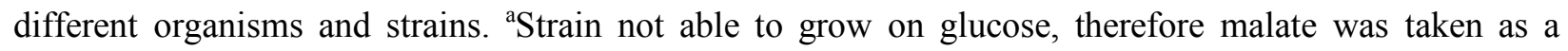
reference high quality carbon source. ' $S$ Strain unable to grow on glucose, so no ratio was calculated. 
bioRxiv preprint doi: https://doi.org/10.1101/2021.05.24.445453; this version posted May 24, 2021. The copyright holder for this preprint (which

was not certified by peer review) is the author/funder, who has granted bioRxiv a license to display the preprint in perpetuity. It is made

Supplementary Information available under aCC-BY 4.0 International license.

Selection for cell yield does not reduce overflow metabolism in E. coli

Rabbers et al.

173

174

175

176

177

178

179

180

181

182

183

184

185

186

187

188

189

190

191

192

193

194

195

196

197

198

199

200

\section{References}

1. Si, F. et al. Invariance of Initiation Mass and Predictability of Cell Size in Escherichia coli. Curr. Biol. 27, 1278-1287 (2017).

2. PARDEE, A. B. \& YATES, R. A. Control of pyrimidine biosynthesis in Escherichia coli by a feedback mechanism. J. Biol. Chem. 221, 757-70 (1956).

3. Jensen, K. F. The Escherichia coli K-12 'wild types' W3110 and MG1655 have an rph frameshift mutation that leads to pyrimidine starvation due to low pyrE expression levels. J. Bacteriol. 175, 3401-7 (1993).

4. Valgepea, K., Adamberg, K. \& Vilu, R. Decrease of energy spilling in Escherichia coli continuous cultures with rising specific growth rate and carbon wasting. BMC Syst. Biol. 5, 106 (2011).

5. Conrad, T. M. et al. Whole-genome resequencing of Escherichia coli K-12 MG1655 undergoing short-term laboratory evolution in lactate minimal media reveals flexible selection of adaptive mutations. Genome Biol. 10, (2009).

6. Nanchen, A., Schicker, A. \& Sauer, U. Nonlinear dependency of intracellular fluxes on growth rate in miniaturized continuous cultures of Escherichia coli. Appl. Environ. Microbiol. 72, 1164-72 (2006).

7. Holms, H. Flux analysis and control of the central metabolic pathways in Escherichia coli. FEMS Microbiol. Rev. 19, 85-116(1996).

8. Valgepea, K. et al. Systems biology approach reveals that overflow metabolism of acetate in Escherichia coli is triggered by carbon catabolite repression of acetyl-CoA synthetase. BMC Syst. Biol. 4, 166 (2010).

9. Renilla, S. et al. Acetate scavenging activity in Escherichia coli: interplay of acetyl-CoA synthetase and the PEP-glyoxylate cycle in chemostat cultures. Appl. Microbiol. Biotechnol. 93, 2109-2124 (2012).

10. Meyer, H.-P., Leist, C. \& Fiechter, A. Acetate formation in continuous culture of Escherichia coli K12 D1 on defined and complex media. J. Biotechnol. 1, 355-358 (1984).

11. Basan, M. et al. Overflow metabolism in Escherichia coli results from efficient proteome allocation. 
bioRxiv preprint doi: https://doi.org/10.1101/2021.05.24.445453; this version posted May 24, 2021. The copyright holder for this preprint (which

was not certified by peer review) is the author/funder, who has granted bioRxiv a license to display the preprint in perpetuity. It is made

Supplementary Information available under aCC-BY 4.0 International license.

Selection for cell yield does not reduce overflow metabolism in E. coli

Rabbers et al.

Nature 528, 99-104 (2015).

202 12. Robak, M. Yarrowia lipolytica specific growth rate on acetate medium supplemented with glucose, 203 glycerol or ethanol. Biotechnologia 6, 23-31 (2007).

204 13. Wendisch, V. F., de Graaf, A. A., Sahm, H. \& Eikmanns, B. J. Quantitative determination of

metabolic fluxes during coutilization of two carbon sources: comparative analyses with

14. Willison, J. C. Pyruvate and Acetate Metabolism in the Photosynthetic Bacterium Rhodobacter capsulatus. Microbiology 134, 2429-2439 (1988).

210 15. Andersen, K. B. \& von Meyenburg, K. Are growth rates of Escherichia coli in batch cultures limited by respiration? J. Bacteriol. 144, 114-23 (1980).

212 16. Johnston, G. C., Ehrhardt, C. W., Lorincz, A. \& Carter, B. L. Regulation of cell size in the yeast 213 Saccharomyces cerevisiae. J. Bacteriol. 137, 1-5 (1979).

214 17. Volkmer, B. \& Heinemann, M. Condition-Dependent Cell Volume and Concentration of 215 Escherichia coli to Facilitate Data Conversion for Systems Biology Modeling. 6, 1-6 (2011).

216 18. Alberghina, F. A., Sturani, E. \& Gohlke, J. R. Levels and rates of synthesis of ribosomal ribonucleic acid, transfer ribonucleic acid, and protein in Neurospora crassa in different steady states of growth. J. Biol. Chem. 250, 4381-8 (1975).

19. Sigala, J.-C. et al. Physiological and transcriptional comparison of acetate catabolism between Acinetobacter schindleri ACE and Escherichia coli JM101. FEMS Microbiol. Lett. 366, (2019). 